\title{
茶園におけるスプリンクラーの多目的利用
}

一汃ん水の効果抢よび施肥, 薬剤散布への利用一

静岡県茶業試験場 此本晴夫・鈴木幸隆・木村政美

\section{On the Multipurpose Usage of Sprinkler in the Tea Field}

\author{
Usage for Irrigation, Manuring and Control of Disease \\ and Insect Damage
}
By Haruo Konomoto, Yukitaka SUZUKI and Masami KIMURA
Shizuoka Tea Experiment Station

\section{1 ま がき}

生産過剩基調下に打汸䒩業の安定的発展を図るため には，需要の増加への努力とともに，良犋で安侹な茶を 供給することが重要な条件である。

茶の品質向上については，優良品種の導入，適期揇採 の励行等を中心に徐々にその成果があらわれつつあり，

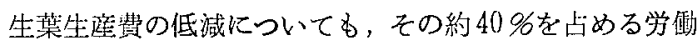
費は，機械化摘採の目ざましい発展に上り労儥の上昇に よる労働費の高腾を最少限に止めつつある。さらに施設 化などにより労墈費の低減が望まれる。

こらした状況のるとで，かん水による良質多収を目ざ した樹園地でのスプリンクラーによる畑地がんがい計画 がなされつつあるが，この施設をさらに有効に利用する ためには，単にかんがい用だけでなく，施肥，病害虫防 除からし尿の畑地還元まで，多目的に使用することが必 要と考党られ，主として樹園地を中心に，かなりの検討 結果が得られている。

当場に批て子富土分場に招いて，本杉ら，小泊ら， 大場が施肥，防除についてこの散水施設の利用を試みて いるが，著者らは，この多目的利用の基幹となるかん水 の効果についての知見が必ずしも十分でないことから， この点の檢討を中心として施肥, 防除についてもあわせ て検討した。

著者らは，この他スプリンクラーの凍霜害，潮風害防 止への利用試みて和り，多目的利用とい5見地から は、これらも含めて考祭すべきであるが，とりあえずか え水，施肥，防除について報告し，大方のご批判を们く 次第である。

\section{2 試 験 方 法}

\section{1 かん水の効果}

(1) 試 験 1
の) 試験区の構成扰よびかん水方法

当場内の牧之原赤黄色土に生垌するからべに(1967年 で10年生の成本園) のほ場に拈いて，表1に示すような 試験区を設け，スプリンクラ一を用いてかん水を行っ た。供試土壤の理化学性は表 2，3抒よび図1のとおり である。（竹中氏調查）

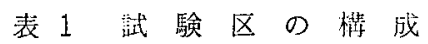

\begin{tabular}{|c|c|}
\hline 試 験 区 & 考 \\
\hline かん水 $\mathrm{A} 区$ & 1 回のかん水量 $20 \mathrm{~mm}$ \\
\hline " B区 & $\begin{array}{l}3 \text { ～11月は } 1 \text { 酋のかん水量 } 20 \mathrm{~mm}, 12 \text { } \\
2 \text { 月は連続無降雨 } 5 \text { 日毎 } 5 \mathrm{~mm} \text { かん水 }\end{array}$ \\
\hline 無汃ん水区 & \\
\hline
\end{tabular}

表 2 からべに園の土缺の比重および孔陌率

\begin{tabular}{c|c|c|c}
\hline 潹さ & 真 此重 & 仮 此重 & 孔除率 \\
\hline $\mathrm{cm}$ & 2.58 & 0.98 & 63 \\
5 & - & 0.95 & 64 \\
10 & - & 0.87 & 67 \\
20 & 2.65 & 0.75 & 73 \\
30 & 2.70 & 0.77 & 72 \\
40 & - & 1.02 & 62 \\
50 & &
\end{tabular}

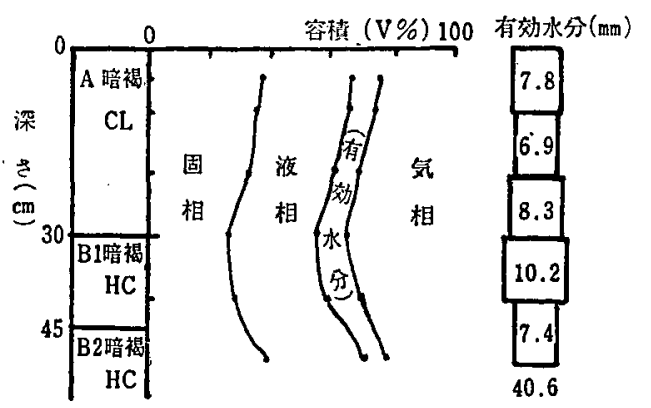

図 1 土壤の三相分布と有効水分䭪 


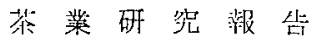

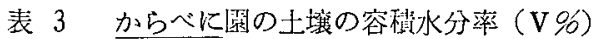

\begin{tabular}{|c|c|c|c|c|c|c|c|c|}
\hline 深さ $\mathrm{pF}$ & 0 & 1.0 & 1.7 & 2.0 & 2.5 & 3.0 & 3.6 & 4.0 \\
\hline 5 & 46.8 & 44.7 & 38.4 & 37.1 & 36.1 . & 32.8 & 28.9 & 23.3 \\
\hline 10 & 48.7 & 45.2 & 38.8 & 36.8 & 39.6 & 32.3 & 29.4 & 24.0 \\
\hline 20 & 50.4 & 48.0 & 36.6 & 34.8 & 36.3 & 33.3 & 28.3 & 24.7 \\
\hline 30 & 50.5 & 47.1 & 39.3 & 37.1 & 33.3 & 31.6 & 27.1 & 19.1 \\
\hline 40 & 54.6 & 52.1 & 42.1 & 39.7 & 38.6 & 34.0 & 29.2 & 20.4 \\
\hline 50 & 56.1 & 48.5 & 38.8 & 37.6 & - & - & 33.3 & 26.1 \\
\hline
\end{tabular}

試験区は 1 区 $120 \mathrm{~m}^{2}$ の 1 区制としたが，収量調查は 1 区の中で 9 反復して行った。かん水は M1 型（ノズルロ 径 $4.2 \mathrm{~mm} \times 3.2 \mathrm{~mm}$ ，散布直径 $21 \mathrm{~m})$ を用いて，未端正 $2.5 \mathrm{~kg} / \mathrm{cm}^{2}$ ， ライザーの高さ $1.5 \mathrm{~m}$ で実施した。かん水 の時期はかん水区の $10 ， 20 ， 30 ， 50,70 \mathrm{~cm}$ の深さに埋 設したテンシオメータのいずれかが吸引压 $200 \mathrm{~cm} ・ \mathrm{H}_{2} \mathrm{O}$ （pF 2.3）に達した時に行った。

なお，この試験は 1968〜'71年にかけて実施し，その 間の茶園の管理は，当場の標準栽培法にしたがった。

(2) 試 験 2

(す) 試験区の構成扩よびかん水方法等 当場内のふじみどり（3〜9年生）の喓場に批て， 表 4 に示すような試験区を設け，1967〜'69年蓄までは 1 区 $51.3 \mathrm{~m}^{2}$ の 1 区制，それ以後は 2 分制して 2 区制と した。供試土境の理化学性は表 5，6，図2に示した。 かん水時期の設定，かん水方法㧍よび管理方法等は試 験 1 に準じて行った。

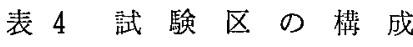

\begin{tabular}{|c|c|}
\hline 試験 区 & 考 \\
\hline かん水区 & $\begin{array}{l}1 \text { 回のかん水龺は } 3 \sim 11 \text { 月は } 20 \mathrm{~mm}, 12 \\
\underset{\text { 水 }}{2} 2 \text { 月は無降水日 } 5 \text { 日ごとに } 5 \mathrm{~mm} \text { かん }\end{array}$ \\
\hline 無かん水区 & 自然降水 \\
\hline
\end{tabular}

表 5 ふじみどり園の土壤の比重および孔隍率

\begin{tabular}{|c|c|c|c|}
\hline 潹さ 項目 & 真 比 重 & 仮比重 & 孔隙率 \\
\hline $5^{\mathrm{cm}}$ & 2.61 & 1.10 & $58.1^{\circ 6}$ \\
\hline 10 & 2.58 & 1.03 & 60.1 \\
\hline 20 & 2.54 & 0.99 & 61.7 \\
\hline 30 & 2.56 & 0.93 & 63.9 \\
\hline 40 & 2.58 & 0.95 & 63.3 \\
\hline 50 & 2.62 & 1.07 & 59.4 \\
\hline 70 & 2.74 & 1.25 & 54.4 \\
\hline
\end{tabular}

表 6 ふじみどり園の土壤の容積水分率（V\%）

\begin{tabular}{|c|c|c|c|c|c|c|c|c|c|c|c|c|}
\hline 樑さ & 0 & 1.0 & 1.3 & 1.5 & 1.7 & 1.8 & 2.0 & 2.2 & 2.5 & 3.0 & 3.6 & 4.0 \\
\hline $\begin{array}{l}\mathrm{cm} \\
5\end{array}$ & 57.0 & 56.1 & 54.7 & 53.5 & 52.6 & 51.5 & 50.6 & 49.2 & 38.8 & 31.2 & 28.1 & 24.5 \\
\hline 10 & 48.8 & 46.6 & 44.5 & 43.4 & 41.9 & 41.3 & 40.5 & 39.2 & 38.4 & 36.1 & 32.2 & 27.7 \\
\hline 20 & 52.5 & 50.6 & 48.5 & 44.7 & 43.3 & 42.4 & 41.5 & 40.1 & 39.8 & 38.8 & 35.3 & 30.1 \\
\hline 30 & 49.4 & 49.0 & 47.0 & 43.4 & 42.5 & 42.1 & 41.5 & 40.3 & 39.9 & 37.5 & 33.0 & 30.1 \\
\hline 40 & 51.3 & 49.9 & 48.4 & 47.1 & 46.3 & 44.2 & 44.6 & 43.5 & 43.0 & 39.0 & 34.5 & 30.0 \\
\hline 50 & 53.6 & 52.4 & 51.6 & 50.5 & 50.0 & 48.9 & 49.0 & 48.0 & 46.5 & 44.5 & 41.7 & 35.2 \\
\hline 70 & 54.9 & 54.0 & 53.5 & 53.1 & 53.0 & 52.6 & 52.8 & 51.4 & 50.9 & 50.4 & 45.6 & 42.6 \\
\hline
\end{tabular}

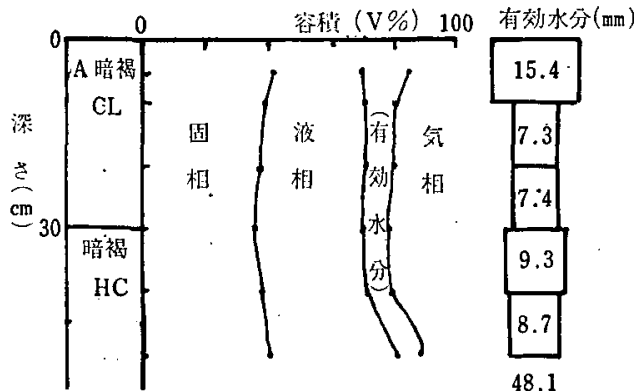

図 2 土塂の三相分布と有効水分量
(3) 試 験 3

当場内の くらさわ（ $5 \sim 10$ 年结）の茶園を用いて，表 7 に示すよ5な試験区を設けて，1969～７1年の3力年 にわたり試験を実施した。供喤士墥の理化学性は表 8 ， 9 おび図3に示した。

表 7 試 験 区 $の$ 棈 成

\begin{tabular}{c|ll}
\hline 試 験 区 & \multicolumn{1}{c}{ 備 } & 考 \\
\hline 多量かん水区 & 1 回のかん水量 $20 \mathrm{~mm}$ & \\
少量かん水区 & " & $10 \mathrm{~mm}$ \\
無かん水区 & 自然降水 & \\
\hline
\end{tabular}


表 8 〈らさわ園の土镜の比重と孔隙率

\begin{tabular}{c|c|c|c}
\hline 深さ & 真 比重 & 仮比重 & 孔 隙率 \\
\hline $\mathrm{cm}$ & 2.65 & 0.94 & 64.7 \\
5 & 2.67 & 0.85 & 67.7 \\
10 & 2.59 & 0.75 & 71.3 \\
20 & 2.57 & 0.72 & 71.9 \\
30 & 2.58 & 0.75 & 71.0 \\
40 & 2.68 & 0.93 & 65.9 \\
50 & 2.68 & 1.05 & 65.9 \\
70 & & & \\
\hline
\end{tabular}

試験区は 1 区 $31.5 \mathrm{~m}^{2}$ の 2 区制で，かん水開始時期お よび管理方法は試験 $1 ， 2$ に準じたが，かん水方法は， 茶株上 $80 \mathrm{~cm}$ の高さで $1 \mathrm{~m}$ 間隔に並列した小ノズル（エ
ルメコノズル，1インチの塩ビパイプに装着）からの噴

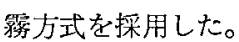

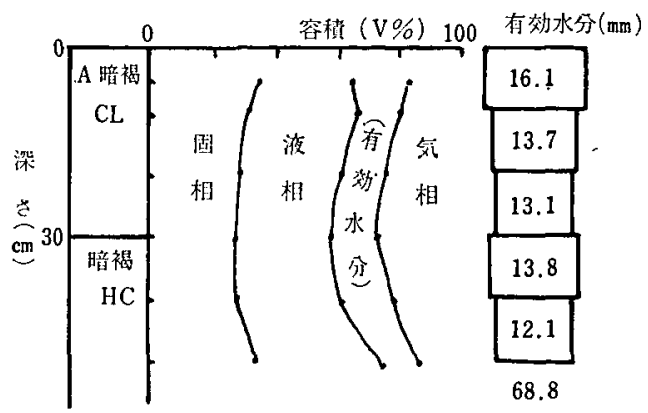

図 3 土㵝の三相分布と有効水分量

表 9 くらさわ園の土壤の容積水分率 $(\mathrm{V} \%$ )

\begin{tabular}{|c|c|c|c|c|c|c|c|c|c|c|c|c|}
\hline 深さ $\mathbf{p F}$ & 0 & 1.0 & 1.3 & 1.5 & 1.7 & 1.8 & 2.0 & 2.2 & 2.5 & 3.0 & 3.6 & 4.0 \\
\hline $5^{\mathrm{cm}}$ & 56.5 & 54.5 & 52.4 & 50.3 & 49.1 & 47.8 & 47.0 & 46.1 & 42.2 & 36.8 & 30.9 & 25.5 \\
\hline 10 & 57.3 & 56.4 & 55.1 & 53.0 & 50.7 & 49.6 & 48.2 & 46.8 & 42.4 & 41.1 & 33.7 & 29.7 \\
\hline 20 & 58.7 & 57.5 & 54.5 & 52.7 & 49.3 & 47.6 & 45.8 & 44.3 & 42.8 & 38.9 & 32.9 & 26.2 \\
\hline 30 & 58.0 & 56.1 & 52.8 & 50.1 & 46.2 & 46.2 & 44.8 & 43.1 & 42.8 & 39.5 & 31.6 & 25.6 \\
\hline 40 & 58.6 & 57.0 & 54.0 & 52.1 & 49.7 & 48.6 & 47.0 & 45.0 & 41.6 & 38.9 & 32.6 & 27.2 \\
\hline 50 & 56.4 & 55.1 & 54.1 & 53.3 & 52.7 & 51.6 & 50.6 & 49.1 & - & 49.5 & 40.9 & 35.4 \\
\hline 70 & 58.3 & 57.5 & 57.1 & 56.3 & 55.5 & 56.5 & 53.6 & 52.7 & 52.3 & 49.3 & 44.6 & 39.3 \\
\hline
\end{tabular}

\section{2 か ん水時 期}

場内の赤黄色士を $1 / 2000$ a のポットに充てんし，やぶ きたを1971年 4 月および1972年 4 月に定植し，表10に示 すよ5な試験区を設けて，1回当たり $10 \mathrm{~mm}$ ずつかん水 して適正なかん水時期を検討した。

表 10 試 験 区 $の$ 構 成

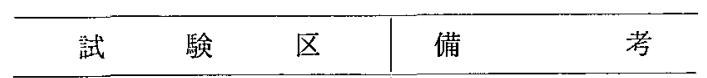

吸引压 $100 \mathrm{~cm} \cdot \mathrm{H}_{2} \mathrm{O}(\mathrm{pF} 2.0) \quad 1$ 回のかん水量 $10 \mathrm{~mm}$

$\Rightarrow 200 " \quad(\mathrm{pF} 2.3)$

$\Rightarrow 400 \Rightarrow$

(pF 2.6)

" $700 "$

(pF 2.8)

1 区のポット数は 3 ポットとし，かん水の指標となる テンシオメータの測定は, ポット土筫の深さ $10 \mathrm{~cm}$ で行 った。本試験は 1971〜'73年の 3 カ年にわたって行った。

\section{3 夜肥の施用}

(1) 液肥散布の効果

1970〜'72年の 3 力年にわたり，場内㤩じみどり（6 ～8 年生) 園を用いて，1区 $10.8 \mathrm{~m}^{2}$ の面積をとり，表 11に示すように，施肥量を主区，肥料の形態を副区とす る分割区法により試験を行った。

この間, 液肥の散布方法は，じょろを用いて新菜のな 、時は 100 倍, 新芽のある時は 200 倍に稀釈して散布し
た。をた惯行区る同量の水を散布し，その他の管理は当 場標準栽培法にしたがった。

散布時期による品貿への影䠽を調查するため, 1972年 に7132 (系統番号) の7 年生を用いて，摘採前 14 日と 28 日に前述の鹉験に用いた同一の液肥を使って処理した場 合の差を検討した。1 区面積 $5.4 \mathrm{~m}^{2} ， 2$ 区制で行った。 液肥の散布はじょろを用い, 稀簬濃度 200 倍, 散有量を $10 \mathrm{~mm}$ とした。

表 11 試 験 区 $の$ 構 成

\begin{tabular}{|c|c|c|}
\hline 主 区 & 副 & 考 \\
\hline 䅺肥区 & $\begin{array}{l}\text { 有機配合十単肥 } \\
\text { 有機配合十液肥 } \\
\text { 年 間 液 肥 }\end{array}$ & $\begin{array}{l}\text { 夏肥を単肥で } 4 \text { 回行 } \\
\text { 夏肥を液肥で } 4 \text { 回行 } \\
\text { 年間 } 8 \text { 回に分施する }\end{array}$ \\
\hline 多肥区 & $\begin{array}{l}\text { 有機配合十単肥 } \\
\text { 有機配合十液肥 } \\
\text { 年 間 液 肥 }\end{array}$ & $\begin{array}{c}\text { 瞟肥区に準ずる } \\
\text { " } \\
\text { 年間 } 9 \text { 回に分施する }\end{array}$ \\
\hline
\end{tabular}

注：多肥区は標肥区の 2 倍量を施す。

(2) 液肥の散布濃度

(ア) 試 驗 1

施用する波肥の潛度について検討するため，場内の 7 年生 7217 (系統番号) 園を用いて，1区 $1.8 \mathrm{~m}^{2}$ の面積を とり，表12-1挔よび表12-2 に示すよ5な二つの試験 を行った。 
表12-1 試 験 区 $の$ 模 成

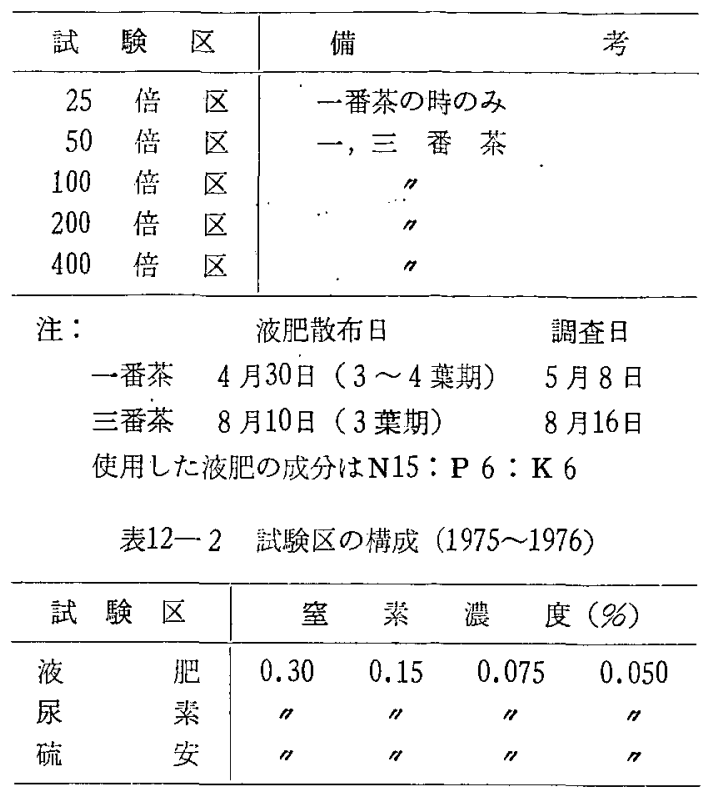

\begin{tabular}{|c|c|c|}
\hline 年次 & 液肥散布日 & 調查日 \\
\hline 1975 & 8月1日（2 证期） & 8 月 9 日 \\
\hline 1976 & 8月 4 日（2䐑期） & 8 \\
\hline
\end{tabular}

すなわち，前者の試験は液肥の施朋涉度を梌詂するも ので，単区制とし，各区 $5 \mathrm{~mm}$ をじょろで敝布し，後者

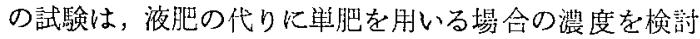
するもので， 2 連制とし，各区 $10 \mathrm{~mm}$ を散布した。

1971年度，すなわち前者の試験期間における気象状況 を示すと，表13のと抽である。

表 13 気象状況

\begin{tabular}{|c|c|c|c|c|c|}
\hline 茶斯 & - & 茶 & & $\equiv$ & 茶 \\
\hline 月日 & $\begin{array}{l}\text { 平 均 } \\
\text { 気 温 }\end{array}$ & 降水量 & 月日 & $\begin{array}{ll}\text { 平 } \text { 均 } \\
\text { 氮 }\end{array}$ & 降水量 \\
\hline 4. 30 & $14.6^{\circ} \mathrm{C}$ & $\mathrm{mm}$ & 8. 10 & $26.2^{\circ} \mathrm{C}$ & \\
\hline 5. 1 & 13.6 & 0.3 & 11 & 26.1 & \\
\hline 2 & 15.4 & & 12 & 28.1 & \\
\hline 3 & 14.6 & 12.1 & 13 & 27.7 & \\
\hline 4 & 13.5 & 56.2 & 14 & 26.7 & \\
\hline 5 & 13.9 & & 15 & 26.0 & \\
\hline 6 & 14.0 & 28.8 & 16 & 26.6 & \\
\hline 7 & 15.5 & & & & \\
\hline 8 & 15.3 & & & & \\
\hline $\begin{array}{l}\text { 平均又 } \\
\text { 俉計 }\end{array}$ & 14.5 & 97.4 & 平 均 & 26.8 & 0 \\
\hline
\end{tabular}

(1) 試 験 2

高濃度の液肥散布時に括ける泊じょ5時期, 水量等を 検討するため，7年生の場内 7132 (采統番号) 園におい て，表14に示すよ 5 な 3 要因を $3 \sim 5$ 水準にとり，1区
$1.8 \mathrm{~m}^{2}$ の単区制で，じょろを用いて 1972 年 8 月 8 日に炕 理し，8月16日に調查した。

表 14 試 験区 の 梳 成

\begin{tabular}{|c|c|c|c|}
\hline 因 & 水 & & 準 \\
\hline 稀 釈 濃 度 & 25倍 & 50 倍 & 100倍 \\
\hline $\begin{array}{l}\text { 液肥散布後洗じ } \\
\text { 上5までの時間 }\end{array}$ & 直後 & 30 分 & 120 分 \\
\hline 洗じょ5水量 & 1,2 & 3 & $5 \mathrm{~mm}$ \\
\hline
\end{tabular}

\section{4 病害虫防除}

スプリンクラーの種類およびその設置間隔について検 討するため，当場内の図 4 に示すよ5な潘場において， M 1 型およびM 2 型スプリンクラーについて比較試験を 行った。

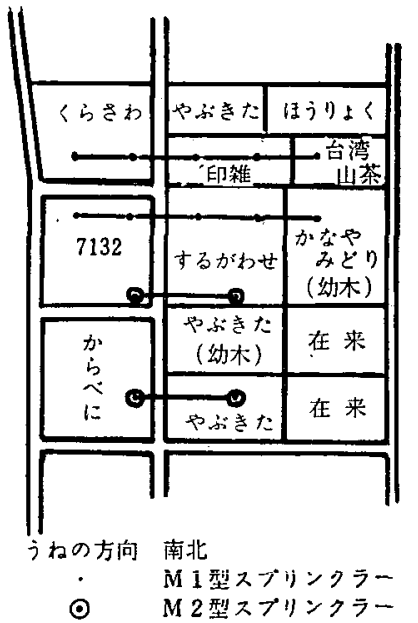

図 4 ほ場の品種の分布とスプ リンクラーの配置

すなわち，供試した M 1 型スプリンクラーは，中閪圧 で口径 $4.8 \mathrm{~mm} \times 3.2 \mathrm{~mm}$, 瀵出仿度 $12^{\circ}$, 水頭生 $2.5 \mathrm{~kg}$ $/ \mathrm{cm}^{2}$ のもので，M2型は中間圧，口径 $6.4 \mathrm{~mm} \times 4.8$ $\mathrm{mm}$ ，噴出触度 $12^{\circ}$ ，水頭压 $3.4 \mathrm{~kg} / \mathrm{cm}^{2}$ のものである。 この 2 種類のスプリンクラーを $\mathrm{M} 1$ 型については $12 \mathrm{~m} \times$ $12 \mathrm{~m}, \mathrm{M} 2$ 型は $20 \mathrm{~m} \times 20 \mathrm{~m}$ の間隔とし, 萫液の稀秎につ いては動噴による压入方式とし，一次稀躯液を作り，二 次稀积で約 10倍（動貲流量：主ポンプ水量＝1：9）之 した。

なお， 2 力年の試験に括ける薬剂散布の実施状況は， 表15のとおりである。

次にカンザワハダ二の防除に括ける散布量と效果との 関係について，M 1 型スプリンクラーを用い，10 a 当た り300，600，1000 l 散布区を設けて検討した。

また，現地の施設について残液量の調查を行った。 
第 46 号 (1977)

表 15 薬郕散布の状況

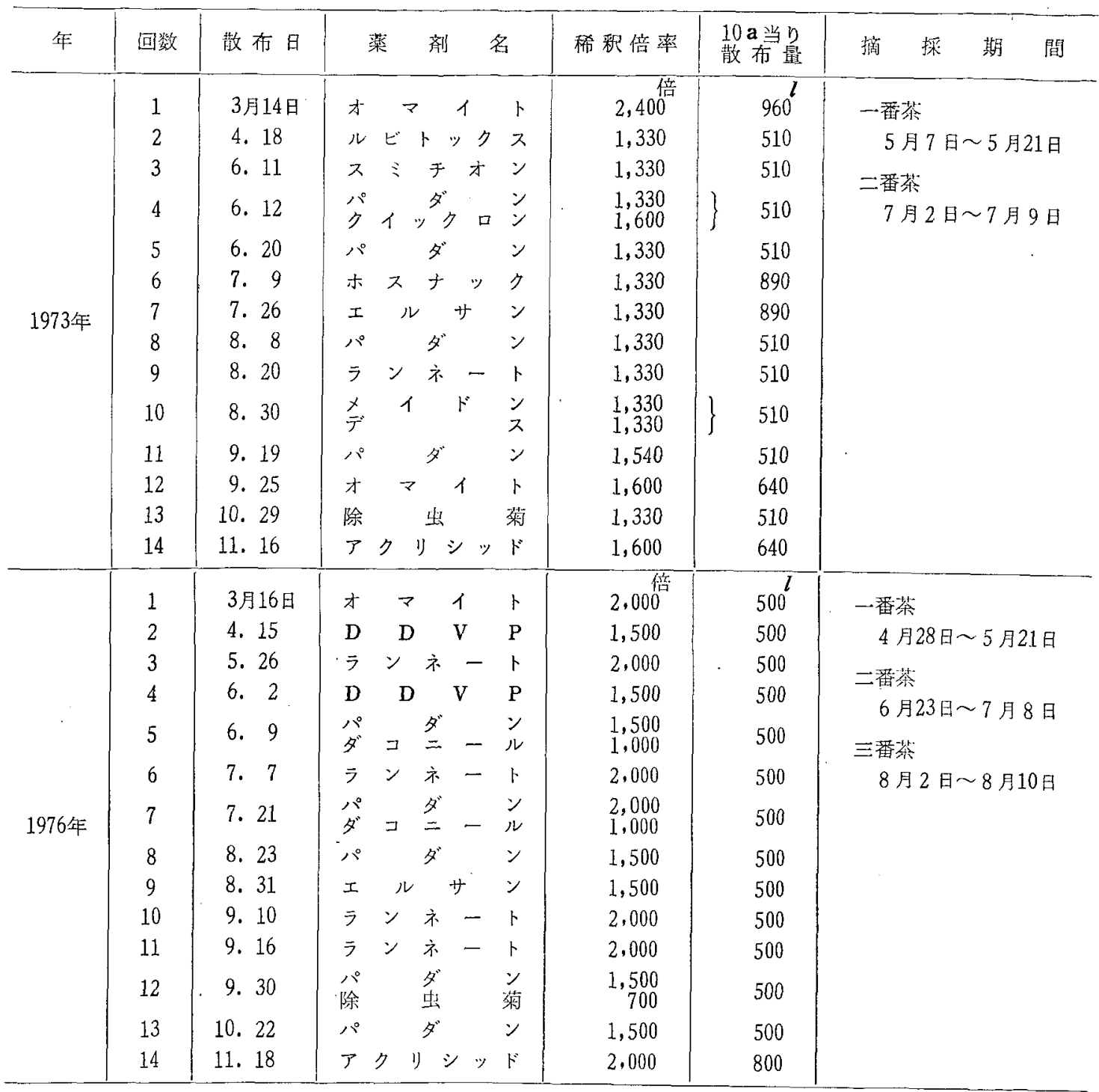

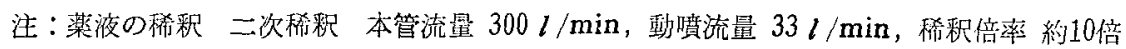

\section{3 試 験 結 果}

\section{1 かん水の効果}

試験期間に当たる 1967〜 72年の月别気象状況を示す と表16のと敊りで，この5ち 1967年は蒸発再は平年並で あったが，萃季の気温はやや高く，降水量は少なく，そ のため連続干天の発生は多かった。

また，1968年は1〜2月は低温であのたが，その後10月 までは活ば平年並に経過し，11〜12月は平年より高温で 降水量は年間かなり多く，特に夏季の雨量が多かった。 次に 1969年は，冬の気温は高かったが，3月以後は平 年並で，年間降水量も平年並であるが，降雨にむらがあ り，連綕干天日数も多かった。

1970年は 3〜 4月が低温で, 降水量も3月をで非常に
少なく，8〜9月も少なかったが，降雨分有がよく長期 間の乾燥はなかった。

さらに 1971年は，武溜は平年留であったが，降水量は 少なく，8月および10〜12月は言い干天日が発生し， 1972年は暖冬年で降水量が多く，降雨の分布もよい年で あった。

このよ5な気象条件のもとで，三つの保水性の異なる ほ場での年間のかん水の頻度をみると，表17のとおりで ある。すなわち保水性の悪いからべに園では 1968～'71 年の 4 年間の平均で 9.3 回，特に 1969年は多く，15回字

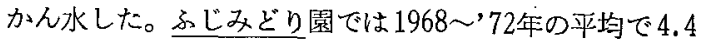
回であり，1972年は降雨分布がよく，1年間に 1 回しか かん水しなかった。保水性の最もよいくらさわ園では， 1969 '71年の 3 年間の平均で 2.7 回，干ばつ年の1969年 
茶業研究報告

表 16 月別気象状況

A)平均気温 $\left({ }^{\circ} \mathrm{C}\right)$

\begin{tabular}{|c|c|c|c|c|c|c|c|}
\hline 月 年 & 1967 & 1968 & 1969 & 1970 & 1971 & 1972 & 平均 \\
\hline 1 & 4.4 & 4.3 & 5.9 & 4.1 & 4.9 & 7.7 & 5.2 \\
\hline 2 & 4.3 & 3.0 & 6.5 & 6.2 & 5.8 & 6.3 & 5.4 \\
\hline 3 & 8.8 & 9.0 & 7.9 & 5.2 & 7.7 & 8.8 & 7.9 \\
\hline 4 & 13.4 & 13.5 & 13.7 & 12.6 & 13.2 & 13.3 & 13.3 \\
\hline 5 & 18.6 & 17.3 & 18.2 & 18.0 & 17.4 & 17.1 & 17.8 \\
\hline 6 & 21.9 & 20.6 & 19.5 & 19.7 & 20.7 & 20.6 & 20.5 \\
\hline 7 & 25.4 & 23.8 & 23.6 & 24.4 & 24.9 & 24.3 & 24.4 \\
\hline 8 & 26.6 & 25.9 & 25.9 & 25.4 & 26.0 & 25.5 & 25.9 \\
\hline 9 & 23.0 & 22.0 & 22.8 & 23.6 & 22.1 & 21.9 & 22.6 \\
\hline 10 & 16.9 & 16.9 & 17.3 & 17.5 & 15.7 & 18.1 & 17.1 \\
\hline 11 & 13.2 & 13.0 & 12.2 & 12.2 & 12.1 & 12.1 & 12.5 \\
\hline 12 & 5.3 & 10.4 & 6.1 & 6.8 & 7.6 & 7.8 & 7.3 \\
\hline 年平均 & 15.2 & 15.0 & 15.0 & 14.7 & 14.9 & 15.3 & 15.0 \\
\hline
\end{tabular}

B）降水 量 $(\mathrm{mm})$

\begin{tabular}{|c|c|c|c|c|c|c|c|}
\hline 月 年 & 1967 & 1968 & 1969 & 1970 & 1971 & 1972 & 平 \\
\hline 1 & 135.4 & 75.4 & 112.1 & 83.6 & 42.0 & 124.3 & 95.5 \\
\hline 2 & 73.7 & 97.2 & 115.6 & 72.1 & 69.7 & 155.9 & 97.4 \\
\hline 3 & 165.8 & 289.6 & 182.6 & 95.8 & 256.6 & 230.5 & 203.5 \\
\hline 4 & 275.9 & 173.6 & 209.3 & 192.3 & 116.8 & 407.6 & 224.3 \\
\hline 5 & 97.2 & 196.8 & 184.0 & 316.9 & 238.0 & 158.0 & 198.5 \\
\hline 6 & 319.4 & 264.2 & 525.0 & 511.4 & 171.6 & 269.0 & 343.4 \\
\hline 7 & 240.2 & 748.4 & 323.4 & 291.7 & 209.9 & 622.9 & 406.1 \\
\hline 8 & 237.8 & 427.3 & 323.4 & 222.0 & 372.5 & 177.3 & 293.4 \\
\hline 9 & 80.3 & 42.8 & 153.0 & 141.4 & 223.0 & 501.6 & 190.4 \\
\hline 10 & 222.0 & 89.1 & 41.8 & 108.1 & 220.9 & 74.9 & 126.1 \\
\hline 11 & 94.4 & 81.7 & 124.6 & 77.1 & 18.4 & 86.0 & 80.4 \\
\hline 12 & 23.4 & 282.0 & 48.8 & 104.2 & 102.4 & 128.0 & 114.8 \\
\hline 計 & 1965.5 & 2768.1 & 2343.6 & 2216.6 & 2041.8 & 2936.0 & 2378.7 \\
\hline
\end{tabular}

C）6日以上干天の続いた回数

\begin{tabular}{c|c|c|c|c|c|c|c}
\hline 月 年 & 1967 & 1968 & 1969 & 1970 & 1971 & 1972 & 平均 \\
\hline 1 & 2 & 2 & 1 & 1 & 2 & 1 & 1.5 \\
2 & 2 & 2 & 2 & 2 & 1 & 1 & 1.7 \\
3 & 1 & 0 & 2 & 2 & 1 & 1 & 1.2 \\
4 & 1 & 0 & 2 & 0 & 2 & 1 & 1.0 \\
5 & 1 & 1 & 1 & 0 & 1 & 1 & 0.8 \\
6 & 1 & 1 & 1 & 1 & 1 & 0 & 0.8 \\
7 & 2 & 1 & 1 & 1 & 1 & 2 & 1.3 \\
8 & 2 & 1 & 2 & 3 & 1 & 1 & 1.7 \\
9 & 1 & 2 & 2 & 1 & 1 & 2 & 1.5 \\
10 & 2 & 2 & 2 & 2 & 1 & 1 & 1.7 \\
11 & 1 & 1 & 3 & 2 & 2 & 2 & 1.8 \\
12 & 2 & 2 & 2 & 2 & 1 & 2 & 1.8 \\
\hline 計 & 18 & 15 & 21 & 17 & 15 & 15 & 16.8 \\
\hline
\end{tabular}

D） 15 日以上干天の続いた回数

\begin{tabular}{|c|c|c|c|c|c|c|c|}
\hline 月 & 1967 & 1968 & 1969 & 1970 & 1971 & 1972 & 平均 \\
\hline 1 & 1 & 1 & 1 & 1 & 1 & & 0. \\
\hline 2 & & & & 1 & & & 0. \\
\hline 3 & & & & 1 & 1 & & 0. \\
\hline 4 & & & & & & & \\
\hline 5 & 1 & & & & & & 0. \\
\hline 6 & & & & & & & 0 \\
\hline 7 & & & 1 & & & 1 & 0.3 \\
\hline 8 & & & & & 1 & & 0. \\
\hline$y$ & & 1 & & & & & 0 . \\
\hline 10 & & & 1 & & 1 & & 0 . \\
\hline 11 & & 1 & & & 1 & & 0 . \\
\hline 12 & 1 & & 1 & 1 & 1 & 1 & \\
\hline 計 & 3 & 3 & 4 & 4 & 6 & 2 & 3. \\
\hline
\end{tabular}


E) 蒸 発 量 $(\mathrm{mm})$

\begin{tabular}{|c|c|c|c|c|c|c|c|}
\hline 月 年 & 1967 & 1968 & 1969 & 1970 & 1971 & 1972 & 平均 \\
\hline 1 & 81.3 & 73.9 & 63.8 & 77.3 & 72.2 & 63.8 & 72.1 \\
\hline 2 & 71.8 & 88.5 & 69.3 & 84.9 & 68.9 & 52.2 & 72.6 \\
\hline 3 & 99.0 & 101.6 & 93.8 & 99.8 & 99.6 & 69.7 & 93.9 \\
\hline 4 & 108.6 & 113.7 & 103.6 & 104.2 & 94.7 & 103.0 & 104.6 \\
\hline 5 & 141.6 & 131.0 & 150.0 & 126.5 & 116.8 & 119.1 & 130.8 \\
\hline 6 & 135.9 & 120.4 & 109.9 & 96.0 & 86.9 & 146.3 & 115.9 \\
\hline 7 & 117.3 & 110.0 & 96.2 & 133.0 & 116.9 & 119.4 & 115.5 \\
\hline 8 & 124.4 & 127.1 & 117.4 & 131.2 & 136.0 & 145.5 & 130.3 \\
\hline 9 & 104.4 & 121.6 & 84.9 & 102.3 & 91.0 & 113.5 & 103.0 \\
\hline 10 & 88.0 & 91.0 & 83.5 & 86.3 & 74.9 & 73.1 & 82.8 \\
\hline 11 & 73.3 & 84.8 & 52.5 & 74.0 & 62.5 & 46.5 & 65.6 \\
\hline 12 & 68.9 & 60.5 & 57.3 & 55.6 & 59.1 & 31.1 & 55.4 \\
\hline 竐 & 1214.5 & 1224.1 & 1082.2 & 1171.1 & 1079.5 & 1083.2 & 1142.4 \\
\hline
\end{tabular}

表 17 試験期間における年間のかん水回数

A) からべに

\begin{tabular}{|c|c|c|c|c|c|c|c|c|c|c|c|c|c|}
\hline 年 & 1 & 2 & 3 & 4 & 5 & 6 & 7 & 8 & 9 & 10 & 11 & 12 & 訪 \\
\hline 1968 & 1 & & & & & 1 & 1 & 1 & 2 & & 1 & & 7 \\
\hline 1969 & & & & & 1 & 2 & 3 & 1 & 3 & 4 & 1 & & 15 \\
\hline 1970 & 1 & & & & & 1 & 1 & 2 & 2 & & 1 & & 8 \\
\hline 1971 & & & & & & & 1 & 2 & 1 & 1 & 2 & 1 & 7 \\
\hline 平均 & & & & & 0.2 & 1.0 & 1.5 & 1.5 & 2.0 & 1.3 & 1.3 & & (10) 9.3 \\
\hline
\end{tabular}

注：計拈よび平均は3～11月について示す。（）内は1969１971年の平均を示す。

B) ふとじみどり

\begin{tabular}{l|l|l|l|l|l|l|l|l|l|l|l|l|l}
\hline 月 & 1 & 2 & 3 & 4 & 5 & 6 & 7 & 8 & 9 & 10 & 11 & 12 & 計 \\
\hline 1968 & & & & & & & 1 & 1 & & & 1 & & 3 \\
1969 & $(1)$ & & & & 1 & & 2 & 2 & 1 & & & & 6 \\
1970 & $(5)$ & $(1)$ & & & & 1 & 1 & 2 & 1 & & 1 & & 6 \\
1971 & $(4)$ & $(2)$ & & & & & 1 & 2 & 1 & & 2 & $(4)$ & 6 \\
\hline 平均 & & & & & 0.2 & 0.2 & 1.3 & 1.8 & 0.8 & & 1.0 & & (6) 4.4 \\
\hline
\end{tabular}

注：1.（）は冬期かん水の回数を示す。

2. 1967年12月から1968年 2 月までの間に計 8 回 $5 \mathrm{~mm}$ ずつかん水した。

3.（は1969～1971年の承均を示す。

C) $\leq 5 \pm わ$

\begin{tabular}{l|l|l|l|l|l|l|l|l|l|l|l|l|l}
\hline 年 & 1 & 2 & 3 & 4 & 5 & 6 & 7 & 8 & 9 & 10 & 11 & 12 & 計 \\
\hline \begin{tabular}{l|l}
1969 \\
1970
\end{tabular} & 1 & & & & 1 & & 1 & 1 & 1 & & & & 4 \\
1971 & & & & & & & 1 & & & & 1 & & 3 \\
\hline 平均 & & & & & 0.3 & & 0.7 & 0.7 & 0.3 & & 0.3 & & 2.7 \\
\hline
\end{tabular}


でも4回であった。

次に間断日数をみると，表 18 のとおりで，保水性の悪 いからべに園の夏季の間断日数は 5〜9日であり，保水 性の良いくらさわ園では8～13日であった。

表 18 試験期間のかん水間断日数

A) か 5 ベ に

\begin{tabular}{l|c|c|c|c|c|c|c}
\hline 月 & 5 & 6 & 7 & 8 & 9 & 10 & 11 \\
\hline 1969 & 7 & & $8,6,5$ & 6,4 & 6,5 & 7 & \\
1970 & & & 8 & 9 & 6 & & \\
1971 & & & & 6,6 & & & 10 \\
\hline 平均 & 7 & & 6.8 & 6.2 & 5.7 & 7 & 10 \\
\hline
\end{tabular}

B) $\leq 5 \pm$ d

\begin{tabular}{|c|c|c|c|c|c|}
\hline 年 月 & 6 & 7 & 8 & 9 & 10 \\
\hline 1969 & & 10,5 & 8 & 8 & 13 \\
\hline
\end{tabular}

次にこれら3つの場でのかん水効果について検討し た結果から，収量への影響をみると，表19のと扣りであ る。すなかちからべに園の場合，かん水の效果は年次や 茶期によって異なり，年間収量では，干ばつ年であった 1969年と，3月や8〜9月に乾燥した 1970年に增収効果 がみられている。またこれを茶期別にみると，一番茶よ りニ〜三番茶での增收效果がみられた。

1)

装 19 かん水がチャの収量に攻ばす影響

\begin{tabular}{|c|c|c|c|c|c|c|c|c|c|c|c|c|}
\hline 年 - 茶期 & \multicolumn{4}{|c|}{1967} & \multicolumn{4}{|c|}{1968} & \multicolumn{4}{|c|}{1969} \\
\hline 䐜 目 & 一 & 二 & 三 & 年 間 & 一 & $=$ & $\equiv$ & 年 間 & $\rightarrow$ & 二 & $\equiv$ & 年 間 \\
\hline かん水 $\mathrm{A} 区$ & 94 & 108 & 95 & 99 & 103 & 90 & 115 & 101 & 103 & 109 & 113 & 109 \\
\hline$" \quad \mathrm{~B}$ 区 & 103 & 114 & 94 & 104 & 101 & 101 & 98 & 100 & 100 & 102 & 119 & 107 \\
\hline 無かん水区 & 100 & 100 & 100 & 100 & 100 & 100 & 100 & 100 & 100 & 100 & 100 & 100 \\
\hline 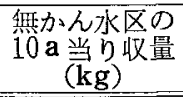 & 455 & 471 & 445 & $1: 371$ & 346 & 525 & 366 & 1237 & 570 & 579 & 580 & 1729 \\
\hline 年・茶期 & & & & & & & & & & 力 & 平 & \\
\hline 項 目 & 一 & 二 & 三 & 年 間 & 一 & 二 & $\equiv$ & 年 間 & 一 & 二 & $\equiv$ & 年 間 \\
\hline かん水 $\mathrm{A}$ 区 & 93 & 100 & 101 & 98 & 84 & 114 & 103 & 102 & 96 & 104 & 106 & 102 \\
\hline B 区 & 107 & 105 & 107 & $\cdot 106$ & 84 & 92 & 96 & 91 & 99 & 102 & 104 & 102 \\
\hline 無かん水区 & 100 & 100 & 100 & 100 & 100 & 100 & 100 & 100 & 100 & 100 & 100 & 100 \\
\hline $\begin{array}{c}\text { 無かん水区の } \\
10 \mathrm{a} \text { 当 収量 } \\
(\mathrm{kg})\end{array}$ & 444 & 602 & 445 & 1491 & 401 & 624 & 440 & 1465 & 443 & 560 & 455 & 1459 \\
\hline
\end{tabular}

注：無かん水区に対する指数で示す。

2) ふじみどり

\begin{tabular}{|c|c|c|c|c|c|c|c|c|c|c|c|c|}
\hline 年 - 茶期 & \multicolumn{4}{|c|}{1968} & \multicolumn{4}{|c|}{1969} & \multicolumn{4}{|c|}{1970} \\
\hline 項 目 & 一 & 二 & $\equiv$ & 年 間 & 一 & 二 & $\equiv$ & 年 間 & $\cdots$ & 二 & $\equiv$ & 年 間 \\
\hline 加儿水区 & 149 & 89 & 94 & 106 & 119 & 92 & 101 & 107 & 105 & 99 & 100 & 101 \\
\hline 無加ん水区 & 100 & 100 & 100 & 100 & 100 & 100 & 100 & 100 & 100 & 100 & 100 & 100 \\
\hline $\begin{array}{c}\text { 無かん水区の } \\
10 \mathrm{a} \text { 当り収量 } \\
(\mathrm{kg})\end{array}$ & 325 & 375 & 673 & 1373 & 494 & 307 & 258 & 1059 & 386 & 376 & 424 & 1186 \\
\hline 年 ·茶期 & \multicolumn{4}{|c|}{1971} & \multicolumn{4}{|c|}{1972} & \multicolumn{4}{|c|}{5} \\
\hline 項 目 & - & $=$ & $\equiv$ & 年 間 & - & $=$ & 三 & 年 間 & $\rightarrow$ & $=$ & $\equiv$ & 年 間 \\
\hline 加儿水区 & 103 & 101 & 99 & 101 & 94 & 97 & 101 & 97 & 114 & 96 & 99 & 102 \\
\hline 無かん水区 & $100^{\circ}$ & 100 & 100 & 100 & 100 & 100 & 100 & 100 & 100 & 100 & 100 & 100 \\
\hline $\begin{array}{c}\text { 無かん水区の } \\
10 \mathrm{a} \text { 当 り収量 } \\
(\mathrm{kg})\end{array}$ & 466 & 611 & 345 & 1423 & 535 & 560 & 381 & 1426 & 441 & 446 & 416 & 1303 \\
\hline
\end{tabular}

注：無かん水区に対する指数で示す。 
3) $\leq$ らさわ

\begin{tabular}{|c|c|c|c|c|c|c|c|c|}
\hline 年・茶期 & \multicolumn{4}{|c|}{1969} & \multicolumn{4}{|c|}{1970} \\
\hline 項 目 & - & $=$ & $\equiv$ & 年 間 & 一 & $=$ & $\equiv$ & 年 閻 \\
\hline 多量かん水区 & 103 & 102 & 92 & 100 & 94 & 108 & 94 & 98 \\
\hline 少量 』 & 102 & 97 & 104 & 100 & 99 & 114 & - 99 & 103 \\
\hline 無かん水区 & 100 & 100 & 100 & 100 & 100 & 100 & 100 & 100 \\
\hline $\begin{array}{c}\text { 無汃え水区の } \\
10 \text { a 当り収量 } \\
(\mathrm{kg})\end{array}$ & 511 & 685 & 377 & 1573 & 687 & 447 & 504 & 1638 \\
\hline 年・茶期 & \multicolumn{4}{|c|}{1971} & \multicolumn{2}{|c|}{3} & 平 & 均 \\
\hline 項 目 & - & $=$ & $\equiv$ & 年 閫 & 一 & $=$ & $\equiv$ & 年 \\
\hline 多量かん水区 & 94 & 93 & 91 & 93 & 97 & 101 & 92 & 97 \\
\hline 少量 " & 89 & 89 & 99 & 91 & 97 & 100 & 101 & 98 \\
\hline 無かん水区 & 100 & 100 & 100 & 100 & 100 & 100 & 100 & 100 \\
\hline $\begin{array}{c}\text { 無かん水区の } \\
10 \mathrm{a} \text { 当り収量 } \\
\text { (kg) }\end{array}$ & 523 & 689 & 352 & 1564 & 574 & 607 & 411 & 1592 \\
\hline
\end{tabular}

注：無かん水区に対する指数で示す。

さらにふじみどり園では，冬季に干ばつのあった 1968 年と，千天の続く回数の多かった 1969年の增収効果が目 立ち，茶期別にみると，一番茶に対する効果が大きかっ た。

なお，〈らさわ園についてみるとほとんど効果がみら れなかった。

次にこうしたかん水が，茶の品質に及ぼす影響につい て調查した結果を示すと，表200と抢りで，からべ園 についてみると，干ばつ年の 1969年に扔けるかん水区は 品質があさり，冬季に干ばつの続いた 1968年も，一番茶 の品質は向上している。しかし，ふじみぞり， くらさわ の雨園では，汪とんで効果はみられなかった。

また，茶期別の品質への影響をみると，からへに闎の 場合に三番茶の品質がやや良くなる傾问を示した。

\section{2 かん水の時期}

適正なかん水開始期を設定するため，罢なる土壤水分 張力下でかん水を開始したところ，1971年の調查結果は 表21，22のと打りである。

すなわち地上部, 地下部の生育は, $\mathrm{pF} 2.3$ 亿達したと きかん水する区が最もまさり, pF 2.6からの場合がこれ に次き， $\mathrm{pF} 2.0$ 抗よび2.7亿達したときのかん水区は少 る傾向を示した。な招，この傾向は表示しなかったが， 1972年も活济同様であった。

\section{3 液 肥 $の$ 施用}

(1) 液肥散布の効果

3 力年継続した試験結果から収量への影響をみると表 23の々おりで，開始当初の1970年は標準施肥区で，年間 液肥を施した区の収量がまさる傾向を示したが，多肥区
では年間液肥の場合，慣行肥料区との間に差はみられな かった（統計処理の上からす有意差はみられない）。し かし，標肥，多肥区ともに慣行肥料区に対し減少する㑯 向がみられた。

また，3力年の年間平均収量でみても，年間液肥区は 標肥区，多肥区とるに慣行区より $3 \sim 4 \%$ 低収で，夏季 のみ液肥を用いた区は慣行区とほとんど差がなかった。

さらに施肥量間の収量差をみると，3年間を通じてい ずれも多肥区の収量がまさる傾向を示した。

次に液肥の施用が茶の品質に及ぼす影響について， 1972年一・二番茶の調查結果を示すと表24のとおりで， 一・二番茶ともに年間液肥区の注うが慣行区より良い品 質を示す場合が多かったが，二番茶の多肥区では液肥区 と惯行区との差が忹とんどなかった。

なお，散布時期による品質の差をみると，表 25 のと拉 りで，摘採28日前に㪄布したるのより，14日前㳻布し たものの浑らがはるかにあさてていた。

(2) 液肥の散布曒度

スプリンクラーを朋いて波肥を散布する場合の濃度に ついて検討するため，一，三番茶の新芽生長時に6 段階 の濃度の液肥を散布し，新芳の被害状況を調查したとこ ろ，表26に示す結果を得た。

すなわち25倍液（䇪菜濃度 $0.6 \%$ ）では $80 \%$ 以上の新 芽に被害が発生し，50倍液（窒素濃度 $0.3 \%$ )では $50 \%$ 程度，100 倍液（窒素浱度 $0.15 \%$ ）では約 $25 \%, 200$ 倍液 （窒素濃度 $0.075 \%$ ）では $5 \%$ 前後の被害が発生した。 また，うねの部位では，頂部は少なくすそ部での被㕩 が多かっだ。さらに観察の結果, 古葉については 100 㥉 


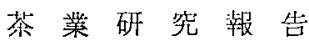

表 20 かん水が茶の品質に及ぼす影悢

1)か らべに

\begin{tabular}{|c|c|c|c|c|c|c|c|c|c|c|c|c|}
\hline 年 - 茶期 & \multicolumn{4}{|c|}{1968} & \multicolumn{4}{|c|}{1969} & \multicolumn{4}{|c|}{1970} \\
\hline 項 目 & 一 & 二 & $\equiv$ & 平均 & 一 & 二 & $\equiv$ & 平均 & 一 & 二 & $\equiv$ & 平均 \\
\hline かん水A区 & 109 & - & 99 & 104 & 103 & 108 & 109 & 105 & 96 & 94 & 105 & 98 \\
\hline " B区 & 105 & - & 103 & 104 & 103 & 108 & 105 & 105 & 101 & 95 & 96 & 97 \\
\hline 無かん水区 & 100 & - & 100 & 100 & 100 & 100 & 100 & 1.00 & 100 & 100 & 100 & 100 \\
\hline 年・茶期 & & & & & & 力 & 平 & 匀 & & & & \\
\hline 項 & $\rightarrow$ & 二 & $\equiv$ & 平均 & - & 二 & $\equiv$ & 平均 & & & & \\
\hline かん水 $\mathrm{A} 区$ & 96 & 103 & 107 & 102 & 101 & 102 & 105 & 102 & & & & \\
\hline$" \quad B 区$ & 96 & 91 & 104 & 97 & 101 & 98 & 102 & 101 & & & & \\
\hline 然售力九水区 & 100 & 100 & 100 & 100 & 100 & 100 & 100 & 100 & & & & \\
\hline
\end{tabular}

注：热汃ん水区に刘する指数で示す。

2) ふ㐅じみどり

\begin{tabular}{|c|c|c|c|c|c|c|c|c|c|c|c|c|}
\hline 年 - 茶期 & \multicolumn{4}{|c|}{1969} & \multicolumn{4}{|c|}{1970} & \multicolumn{4}{|c|}{1971} \\
\hline 項 目 & 一 & $=$ & 三 & 平均 & - & 二 & $\equiv$ & 平均 & $\cdots$ & $\Rightarrow$ & 三 & 平均 \\
\hline か儿水区 & 94 & 95 & 101 & 97 & 101 & 102 & 101 & 101 & 99 & 99 & - & 99 \\
\hline 無か儿水区 & 100 & 100 & 100 & 100 & 100 & 100 & 100 & 100 & 100 & 100 & - & 100 \\
\hline 年. 茶期 & & & & & & カ & 平 & 与 & & & & \\
\hline 項 目 & $\rightarrow$ & 二 & $\equiv$ & 平均 & 一 & 二 & $\equiv$ & 平 均 & & & & \\
\hline か九水区 & 99 & 102 & - & 101 & 98 & 100 & 101 & 100 & & & & \\
\hline 县かん水区 & 100 & 100 & - & 100 & 100 & 100 & 100 & 100 & & & & \\
\hline
\end{tabular}

注：無かん水区に刘する指数で示す。

3) $\leq 5$ 巳

\begin{tabular}{|c|c|c|c|c|c|c|c|c|c|c|c|c|}
\hline 年- 茶期 & \multicolumn{4}{|c|}{1969} & \multicolumn{4}{|c|}{1970} & \multicolumn{4}{|c|}{ 均 } \\
\hline 項 目 & 一 & 二 & $\equiv$ & 平均 & - & $=$ & $\equiv$ & 平均 & 一 & 二 & $\equiv$ & 平均 \\
\hline 多量か儿水区 & 103 & 100 & 101 & 101 & 97 & 101 & 99 & 99 & 100 & 101 & 100 & 100 \\
\hline 少量か九水区 & 103 & 100 & 102 & 102 & 94 & 99 & 99 & 97 & 99 & 100 & 101 & 100 \\
\hline 扫かん水区 & 100 & 100 & 100 & 100 & 100 & 100 & 100 & 100 & 100 & 100 & 100 & 100 \\
\hline
\end{tabular}

注：無かん水区に詨する指数で示す。

程度でも被嗐は臣とんどなく，50倍液では望の先端が褐 変した。

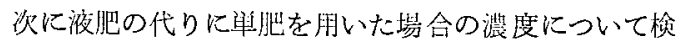
傠した結果を亦すと，表27のとおりである。すなわち肥 料の種類別にみると, 液肥と尿糸では差がなく，硫安は

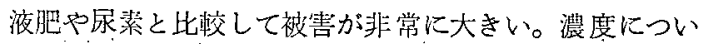

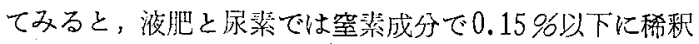

すれば被害は少ないが，硫努では 0.05\%でも 9096近い䉼 苛に被害が発生した。

さらに施肥における散布水嘿を少なくするため，语灌 度の液肥を散竹し，洗じょうする場合の液肥散布後の経 過時間と水量について検討した。

すなわち液肥散布後洗じょ5、なでの時間と被韭第率と の関係は図 5 のと拈りで，時間の経過とともに洗じょう 


$$
\text { 第 } \left.46 \text { 号 (1 } 9 \begin{array}{llll} 
& 9 & 7
\end{array}\right)
$$

表 21 力 几 水回数

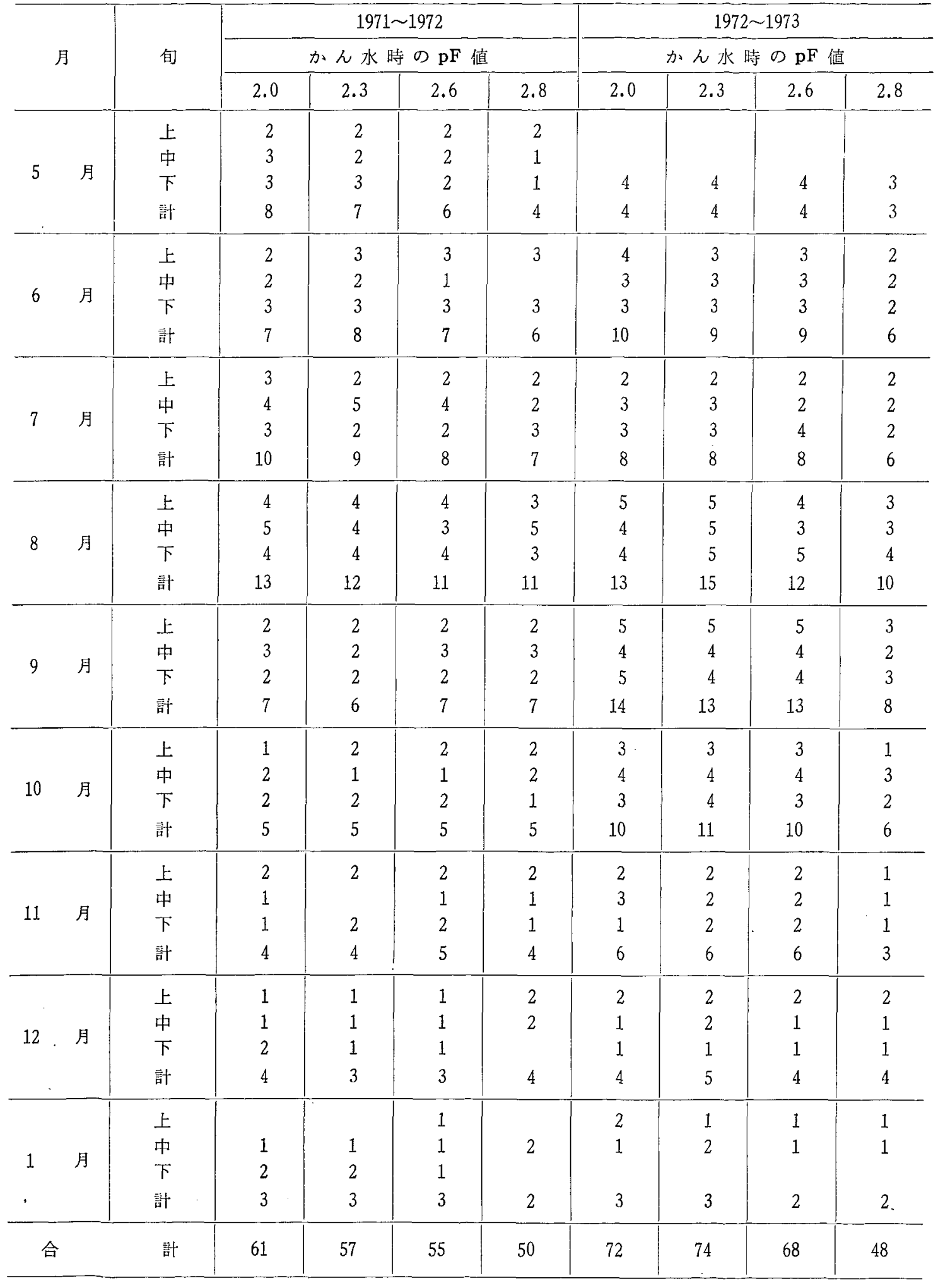

効果は低下した。特に葉の表面が乾いた 120 分後ではあは，液肥散布直後に敬水した場合， 25 倍液では $4 \mathrm{mm，}$ まり効果はみられなかった。水量と被輩芽率との関係で 50 倍液では $3 \mathrm{~mm}, 100$ 倍液では $1 \sim 2 \mathrm{~mm}$ 程度の水で 
表 22 かん水開始期を異にした場合のチャの生劣状沉（1971）

A)

\begin{tabular}{|c|c|c|c|c|c|c|c|c|}
\hline 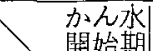 & \multicolumn{2}{|c|}{$\mathrm{pF} 2.0$} & \multicolumn{2}{|c|}{$\mathrm{pF} 2: 3$} & \multicolumn{2}{|c|}{$\mathrm{pF} 2.6$} & \multicolumn{2}{|c|}{$\mathrm{pF} 2.8$} \\
\hline 月日 & 樹 高 & 葉 数 & 樹 & 葉 & 啮 & . 葉 & 樹 & 葉 \\
\hline 5. 27 & $\begin{array}{c}\mathrm{cm} \\
34.7\end{array}$ & $\begin{array}{l}\text { 枚 } \\
25.7\end{array}$ & $\begin{array}{c}\mathrm{cm} \\
37.3\end{array}$ & $25.3^{\text {枚 }}$ & $\begin{array}{l}{ }_{36.0}^{\mathrm{cm}} \\
\end{array}$ & $29.3^{\text {枚 }}$ & $\begin{array}{l}\mathrm{cm} \\
35.7\end{array}$ & 29.7 \\
\hline 7. 6 & 40.0 & 31.0 & 41.7 & 30.3 & 40.3 & 32.7 & 39.3 & 33.0 \\
\hline 8. 7 & 44.1 & 59.0 & 51.0 & 58.7 & 48.7 & 63.0 & 43.7 & 57.3 \\
\hline 9. 7 & 46.0 & 67.0 & 55.0 & 58.0 & 50.7 & 71.7 & 44.0 & 56.0 \\
\hline 10. 11 & 46.3 & 84.0 & 56.7 & 61.3 & 53.0 & 84.0 & 46.0 & 61.0 \\
\hline
\end{tabular}

B)

\begin{tabular}{|c|c|c|c|c|c|c|c|c|c|c|c|}
\hline \multirow{2}{*}{ 方儿水 } & \multicolumn{3}{|c|}{ 地上部（風乾重） } & \multirow{2}{*}{$\begin{array}{l}\text { 地下 部 } \\
\text { (風乾重) }\end{array}$} & \multirow{2}{*}{ 最長根長 } & \multirow{2}{*}{ 葉面筧 } & \multirow{2}{*}{$\begin{array}{l}\text { 風乾重 } \\
\text { 合 }\end{array}$} & \multirow{2}{*}{ 幹 } & \multirow{2}{*}{ 径 } & \multirow{2}{*}{ 葉 } & \multirow{2}{*}{ 数 } \\
\hline & 葉 重 & 茎 重 & 計 & & & & & & & & \\
\hline $\mathrm{pF} 2.0$ & 9.63 & $\begin{array}{r}9 \\
9.58\end{array}$ & $19.20^{\mathrm{g}}$ & $29.86^{g}$ & $\begin{array}{c}\mathrm{cm} \\
45.5\end{array}$ & ${ }_{714.75} \mathrm{~cm}^{2}$ & $49.06^{g}$ & & $\begin{array}{l}\mathrm{mm} \\
9.1\end{array}$ & & 74 \\
\hline 2.3 & 13.38 & 9.90 & 23.28 & 35.93 & 49.0 & 926.35 & 59.21 & & 9.1 & & 67 \\
\hline 2.6 & 12.13 & 6.34 & 18.46 & 22.63 & 42.5 & 705.45 & 41.09 & & 8.2 & & 77 \\
\hline 2.8 & 6.89 & 7.01 & 13.90 & 28.31 & 33.5 & 493.55 & 42.20 & & 7.4 & & 54 \\
\hline
\end{tabular}

注： 1 株当たり 3 反復の平均值を示す。

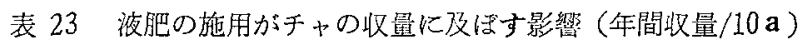

A) 収 量

\begin{tabular}{|c|c|c|c|c|c|c|c|c|c|}
\hline \multirow{2}{*}{ 施肥量 } & \multirow{2}{*}{$\begin{array}{l}\text { 年次 - 項目 } \\
\text { 肥料の種類 }\end{array}$} & \multicolumn{2}{|c|}{1970} & \multicolumn{2}{|c|}{1971} & \multicolumn{2}{|c|}{1972} & \multirow{2}{*}{$\begin{array}{l}3 \text { 平年 } \\
\text { 均 }\end{array}$} & \multirow{2}{*}{ 指 数 } \\
\hline & & 収 量 & 指 数 & 収 量 & 指 数 & 収量 & 指 数 & & \\
\hline 標 & 有機配合十単肥 & $\begin{array}{c}\mathrm{kg} \\
1204\end{array}$ & 100 & $\begin{array}{r}\mathrm{kg} \\
1328\end{array}$ & 100 & $\begin{aligned} \mathrm{kg} \\
1413^{2}\end{aligned}$ & 100 & $\begin{array}{r}\mathrm{kg} \\
1315\end{array}$ & 100 \\
\hline 肥 & 有機配合十液肥 & 1284 & 107 & 1317 & 99 & 1369 & 97 & 1323 & 101 \\
\hline 区 & 年 問 溜 肥 & 1335 & 111 & 1284 & 97 & 1203 & 85 & 1274 & 97 \\
\hline 多 & 有機配合十笚肥 & 1345 & 112 & 1376 & 104 & 1517 & 107 & 1412 & 107 \\
\hline 肥 & 有機配合十液肥 & 1373 & 114 & 1373 & 103 & 1506 & 107 & 1417 & 108 \\
\hline 区 & 年 間 液 肥 & 1328 & 110 & 1317 & 99 & 1403 & 99 & 1349 & 103 \\
\hline
\end{tabular}

B）年間収量の分散分析

\begin{tabular}{|c|c|c|c|c|c|c|c|c|c|c|c|c|}
\hline & \multicolumn{4}{|c|}{1970} & \multicolumn{4}{|c|}{1971} & \multicolumn{4}{|c|}{1972} \\
\hline & S.S & df & F & $F_{0}$ & S.S & $\mathrm{df}$ & F & $F_{0}$ & S.S & $\mathrm{df}$ & $F$ & $F_{0}$ \\
\hline 施肥量 (A) & 29502.08 & 1 & 74.36 & $6.52^{*}$ & 5002.08 & 1 & 25.00 & 6.28 & 10.1 & 1 & & \\
\hline ブロック（R) & 16650.75 & 1 & 41.97 & $11.55^{*}$ & 690.10 & 1 & 3.45 & & 64974.1 & 1 & 5.92 & \\
\hline 誤 差 $\left(\mathrm{E}_{1}\right)$ & 396.75 & 1 & & & 200.07 & 1 & & & 10980.7 & 1 & & \\
\hline 肥料の種類 (B) & 8124.50 & 2 & 2.47 & 1.58 & 25980.5 & 2 & 29.96 & $16,30^{*}$ & 60232.66 & 2 & 23.26 & 10.16 \\
\hline$A \times B$ & 10900.67 & 2 & 3.31 & & 3643.17 & 2 & 4.20 & & 12612.64 & 2 & 4.87 & 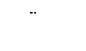 \\
\hline 詔 差 $\left(\mathrm{E}_{2}\right)$ & 6587.5 & 4 & & & 1734.16 & 4 & & & 5180.7 & 4 & & \\
\hline 計 & 72162.25 & 11 & & & 37250.25 & 11 & & $\therefore$ & 153990.9 & 11 & & \\
\hline
\end{tabular}


表 24 液肥の施用が茶の品質に及活す影響

A）一番茶

\begin{tabular}{|c|c|c|c|c|c|c|c|c|c|}
\hline \multirow{2}{*}{\multicolumn{2}{|c|}{ 試戨区 }} & \multicolumn{2}{|l|}{ 外 } & 見 & \multicolumn{2}{|c|}{ 内 } & \multicolumn{2}{|c|}{ 容 } & \multirow{2}{*}{ 合 計 } \\
\hline & & 形 状 & 色 沢 & 該 & 香 気 & 水 色 & 滋味 & 棓 & \\
\hline \multirow[t]{2}{*}{ 標 } & 有㙨配合十単肥 & 16.0 & 15.0 & 31.0 & 15.0 & 15.5 & 14.0 & 44.5 & 75.5 \\
\hline & 有機配合十液肥 & 16.5 & 16.0 & 32.5 & 16.0 & 16.0 & 15.5 & 47.5 & 80.0 \\
\hline 肥 & 年 間 液 肥 & 15.5 & 15.5 & 31.0 & 16.0 & 16.0 & 15.0 & 47.0 & 78.0 \\
\hline \multirow[t]{2}{*}{ 多 } & 有機配合十単肥 & 17.0 & 16.0 & 33.0 & 16.0 & 16.0 & 16.5 & 48.5 & 81.5 \\
\hline & 有機配合十液肥 & 16.5 & 15.5 & 32.0 & 15.5 & 16.0 & 16.0 & 47.5 & 79.5 \\
\hline 肥 & 年 間 液 肥 & 16.0 & 15.0 & $31.0^{\circ}$ & 16.5 & 16.5 & 16.0 & 49.0 & 80.0 \\
\hline
\end{tabular}

B) 二 番 茶

\begin{tabular}{|c|c|c|c|c|c|c|c|c|c|}
\hline \multirow{2}{*}{\multicolumn{2}{|c|}{ 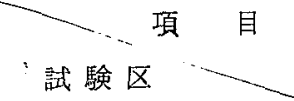 }} & \multicolumn{2}{|l|}{ 外 } & & \multicolumn{2}{|c|}{ 内 } & \multicolumn{2}{|c|}{ 容 } & \multirow{2}{*}{ 合 計 } \\
\hline & & 形 状 & 色 沢 & 計 & 香 気 & 水 色 & 滋昧 & 計 & \\
\hline \multirow[t]{2}{*}{ 標 } & 有機配合十笚肥 & 10.5 & 12.0 & 22.5 & 11.0 & 11.0 & 11.0 & 33.0 & 55.5 \\
\hline & 有機配合十液肥 & 11.0 & 12.5 & 23.5 & 11.5 & 13.0 & 12.5 & 37.0 & 60.5 \\
\hline 肥 & 年 間 液 肥 & 12.5 & 13.0 & 25.5 & 13.0 & 13.5 & 13.0 & 39.5 & 65.0 \\
\hline \multirow[t]{2}{*}{ 多 } & 有機配合+単肥 & 10.0 & 12.0 & 22.0 & 12.0 & 12.5 & 12.0 & 36.5 & 58.5 \\
\hline & 有機配合十液肥 & 12.0 & 13.0 & 25.0 & 12.0 & 12.0 & 13.0 & 37.0 & 62.0 \\
\hline 肥 & 年 間 液 肥 & 13.0 & 13.5 & 26.5 & 12.5 & 12.0 & 13.0 & 37.5 & 64.0 \\
\hline
\end{tabular}

表 25 散布時期に上る䒩の品質

\begin{tabular}{|c|c|c|c|c|c|c|c|c|}
\hline 項 自 & 外 & & 観 & p & & & & \\
\hline 散布時期 & 形 状 & 色 沢 & 計 & 查 気 & 水 色 & 滋 味 & 計 & 公 \\
\hline 揇採前28日処理 & 13.0 & 13.0 & 26.0 & 13.0 & 14.0 & 13.0 & $\dot{4} 0.0$ & 66.0 \\
\hline 摘採前14日処理 & 14.0 & 14.0 & 28.0 & 14.0 & 14.0 & 14.0 & 42.0 & 70.0 \\
\hline
\end{tabular}

表 26 被害芽率 (1971)

\begin{tabular}{|c|c|c|c|c|}
\hline \multirow{2}{*}{$\begin{array}{l}\text { 時期 - 部位 } \\
\text { 稀瀵倍率 }\end{array}$} & \multirow{2}{*}{ 頂 ${ }^{\text {番芲 }}$} & $\equiv$ & 番 & 茶 \\
\hline & & 頂 部 & すと部 & 平 均 \\
\hline - .25 倍 区 & $\begin{array}{c}96 \\
84\end{array}$ & 96 & 96 & 96 \\
\hline 50 & 56 & 52.5 & 54.8 & 53.7 \\
\hline 100 & 24 & 22.4 & 29.7 & 26.1 \\
\hline 200 & 3 & 1.5 & 9.2 & 5.4 \\
\hline 300 & - & 0 & 4.0 & 2.0 \\
\hline 400 & 0 & - & - & - \\
\hline
\end{tabular}

表 27 被害芽率

\begin{tabular}{|c|c|c|c|c|}
\hline 濃 度 & 液 肥 & 尿 素 & 硫 安 & 備 \\
\hline $0.30^{\circ}$ & 6.8 & 5.1 & 91.7 & $\begin{array}{l}\text { 液肥の場含 } \\
50 \text { 偣に当たる }\end{array}$ \\
\hline 0.15 & 1.4 & 0.7 & 49.2 & ${ }_{100}^{7}$ \\
\hline 0.075 & & 0.6 & 12.2 & 200 \\
\hline 0.050 & 1.6 & 0.7 & 19.1 & 300 \\
\hline
\end{tabular}




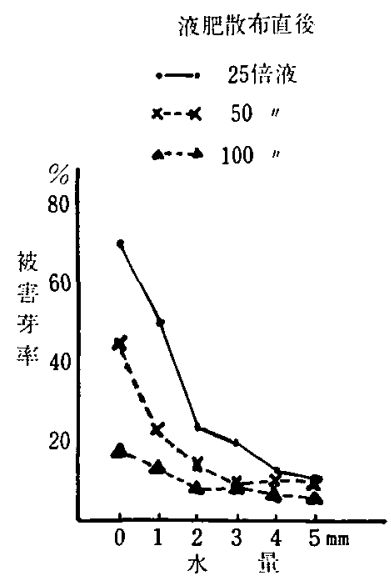

液肥䔩不书30分後
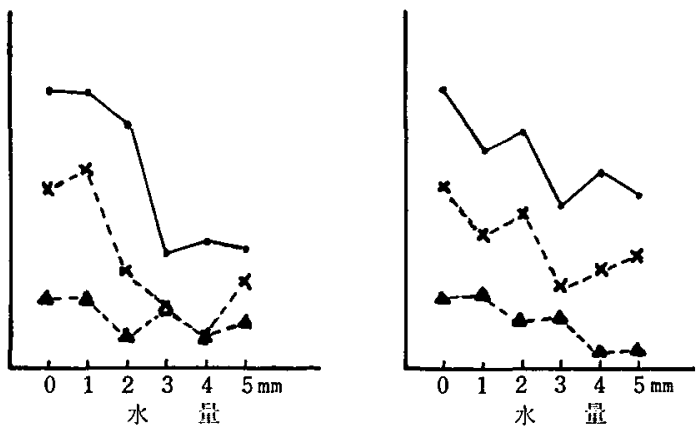

図 5 液肥散布後の洗じょ5の効果

洗じょ5すれば被害は非常に少なくなった。

\section{4 病害虫防除}

1973年の試験は，ほ場の間辺にパートサークルスプリ ンクラーを使用しなかったため，湟周辺の散布量が少 なく，防除效果の劣る所が欢られたため，淔度をやや濃 くしたところ, 使用農薬量が動噴の 1.9 倍程度となっ た。したがって 1976年は配管を修正し，濃度を薄くして 散布した。その場合の農薬量は動噴の 1.5 倍程度となっ たが，年間スプリンクラーのみによる防除を行った結 果，防除効果としては注涪満足できるあのであった。

次に使用したM 1 型，M2型のスプリンクラーについ てその均等度を調査した結果を示すと表28のとおうであ る。すなわち均等係数 $(\mathrm{Cu})$, 散水效率 $(\mathrm{Ep})$ とすに風 速のいかんにかかわらず，M2型の方があさっていた。 またこの両者について，カンザワハダニ，チャハマキ， チャノホソガ，チャノキイロアザミウマなどの防除効果 を調査した結果は，表29のとおりで，両者とも実害はな く，防除効果はかなり高かったが，いずれの害虫に対し てもM1型の汪らが防除勃果はまさる傾向を示した。
表 28 スプリンクラーの散水の均等度

\begin{tabular}{|c|c|c|c|c|c|}
\hline 型 式 & 風向 & 風 速 & 均等係数 & 散水効率 & $\begin{array}{l}\text { 平 均散水深 } \\
\end{array}$ \\
\hline \multirow{7}{*}{ M 1 型 } & $E$ & 2.2 & 63.7 & 49.6 & $\begin{array}{c}\mathrm{mm} \\
0.9\end{array}$ \\
\hline & $\mathrm{E}$ & 2.8 & 56.6 & 41.5 & 1.5 \\
\hline & $\mathrm{E}$ & 2.9 & 58.0 & 43.5 & 1.7 \\
\hline & $\mathrm{E}$ & 3.7 & 53.6 & 45.2 & 0.6 \\
\hline & $W$ & 1.0 & 68.7 & 59.0 & 0.6 \\
\hline & $\mathrm{SW}$ & 1.6 & 53.4 & 34.1 & 1.6 \\
\hline & sW & 1.9 & 53.7 & 40.5 & 1.5 \\
\hline \multirow{8}{*}{ M 2 型 } & $\mathrm{E}$ & 2.7 & 68.4 & 51.7 & 0.8 \\
\hline & $\mathrm{E}$ & 2.8 & 71.9 & 54.1 & 1.4 \\
\hline & $\mathrm{E}$ & 2.9 & 68.9 & 56.6 & 1.4 \\
\hline & $\mathrm{E}$ & 2.9 & 63.4 & 53.1 & 1.5 \\
\hline & $\mathbf{E}$ & 3.7 & 60.6 & 44.0 & 0.6 \\
\hline & W & 1.0 & 63.6 & 44.8 & 0.5 \\
\hline & $\mathrm{SW}$ & 1.6 & 72.4 & 59.2 & 1.6 \\
\hline & sW & 1.9 & 69.9 & 61.8 & 1.5 \\
\hline
\end{tabular}

表 29 スプリンクラーの型式と防除効果

A）カンザワハダニ (30枚調查, M1型区 16 所, M 2 型 20 力所の平均)

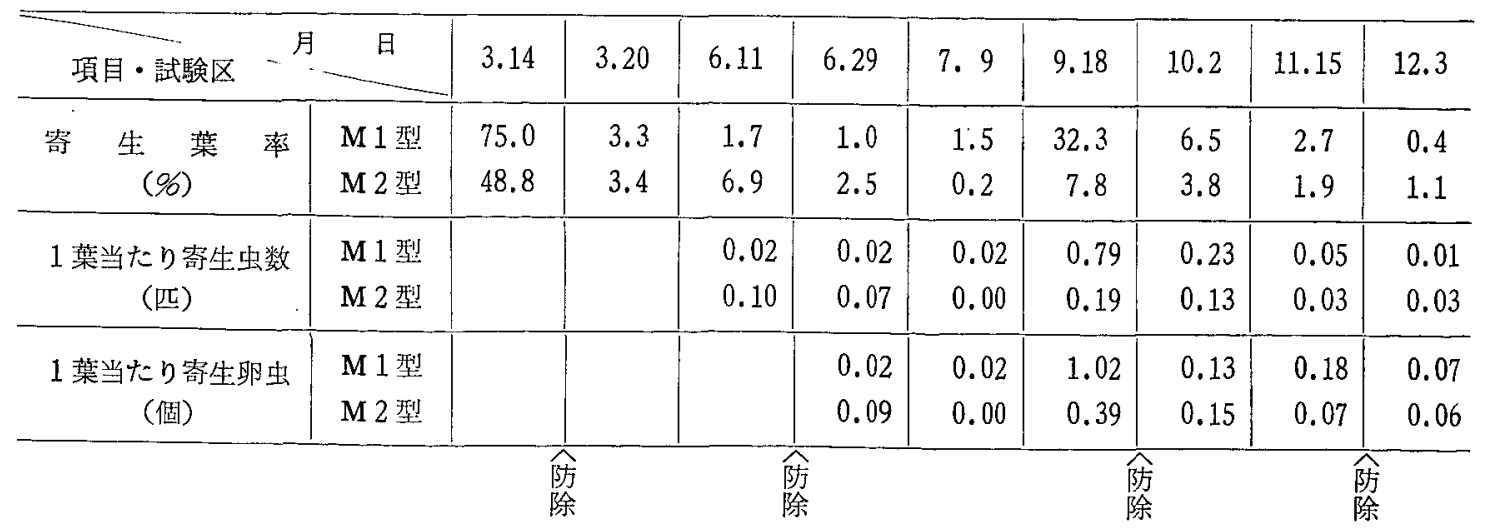




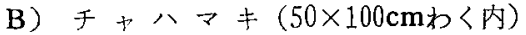

\begin{tabular}{|c|c|c|c|}
\hline 調査日 & 試 験 区 & 虫 数 & 考 \\
\hline 7月23日 & $\begin{array}{lll}\text { M } & 1 & \text { 型 } \\
\text { M } & 2 & \text { 型 } \\
\text { (参) 隣接慣行区 }\end{array}$ & $\begin{array}{l}0.39 \\
1.56 \\
3.53\end{array}$ & $\begin{array}{l}M 1 \text { 型 } 16 \text { 力所 } \\
M 2 \text { 型 } 20 \text { 力所 } \\
\text { の平均 }\end{array}$ \\
\hline
\end{tabular}

C） サンカクハマキ $(50 \times 100 \mathrm{~cm}$ 内)

\begin{tabular}{|c|c|c|c|}
\hline 調 查 日 & 試 験 区 & 生存虫数 & 考 \\
\hline & $\begin{array}{lll}\mathbf{M} & 1 & \text { 型 } \\
\text { M } & 2 & \text { 型 } \\
\end{array}$ & $\begin{array}{l}0.13 \\
0.10\end{array}$ & $\begin{array}{l}\text { M } 1 \text { 型 } 16 \text { 力 } \\
\text { M2 型 } 20 \text { 力 } \\
\text { 平均 }\end{array}$ \\
\hline
\end{tabular}

D) スリ $ッ フ^{\circ}$ ス

虫数（10回はたきおとし）

\begin{tabular}{|c|c|c|c|c|}
\hline \multirow{2}{*}{ 侙嗝区 } & \multicolumn{2}{|c|}{ 調 查 日 } & \multirow{2}{*}{$\begin{array}{c}\text { 防除率 } \\
(\%)\end{array}$} & \multirow{2}{*}{ 俑 } \\
\hline & 6.20 & 6.23 & & \\
\hline & $22.0^{\text {頭 }}$ & $8.5^{\text {頭 }}$ & 61.4 & \multirow{2}{*}{$\begin{array}{l}M 1 \text { 型 } 16 \text { 所 } \\
M 22 \text { 型 } 20 \text { 力 } \\
\text { の平均 }\end{array}$} \\
\hline M 2型 & 19.2 & 9.9 & 48.4 & \\
\hline
\end{tabular}

また防除郊果に及ぼす散布時の風速の影響について， パダン水和剂の 1300 倍液を桼速 $2.0 \mathrm{~m} / \mathrm{sec}, 6.0 \mathrm{~m} / \mathrm{sec}$ のときに $510 l / 10 \mathrm{a}$ を散布した。その時のチャノホソガ の生存虫数を示すと図 6 のとおりで，風速 $6 \mathrm{~m} / \mathrm{sec}$ の場 合には效果にむらがあるのに刘し，2.0 m/sec $の$ 風速下 ではもらが少なくなっている。

次に隣り合5スプリンクラーの敬布範梱が交差する塯 合と交差しない場合について；その近辺の防除効果に与 える影響を検討するため，M2型スプリンクラ一（散布 半径約 $15 \mathrm{~m}$ ) を用いてチャノホソガを対象として調查し た。その結果は図7のとおりで，スプリンクラーから7 〜 $8 \mathrm{~m}$ 蓶れたところから效果の落ちるのがみられ，特に スプリンクラーの反対侧のうね面の効果が考った。しか し交差するように散有した場会には，効果は比較的均一 となった。

次に風向を異にした場合の散水の分布状態を示すと図 8のとおりである。図 8一Aは追風の場合で, スプリン クラー側のう权面は非常によくかかるが，反対側はかか りにくく，図 8一-Bに示すよ5に向い風の場合は，押し 返されるように水洬が落下するので，スプリンクラーの 反対側の5ね面当比較的散布量が多くなった。

さらにカンザワハダ二の防除における散布量と効果と の関係について検討した。その結果，表30に示すように 散布量が多い活ど防除効果は高く、スプリンクラー側の らね面の效果が高かった。

また同じスプリンクラーを用いて，薬液の付着状態を 調査した結果は図9のとおりで，散布量が堌すにつれて 薬液の付着はよくなった。特にカンザワハダ二の防除で 問題となる葉弿への付着が良くなった。これをうれの部

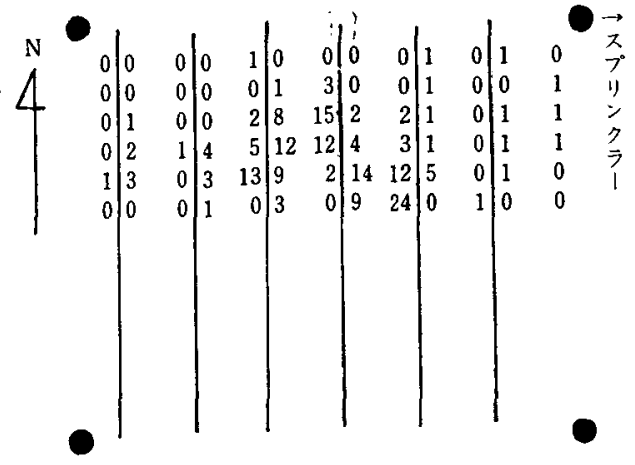

風の强い日 (風向 $\mathrm{N}$ 風速 $6.0 \mathrm{~m} / \mathrm{s}$ )

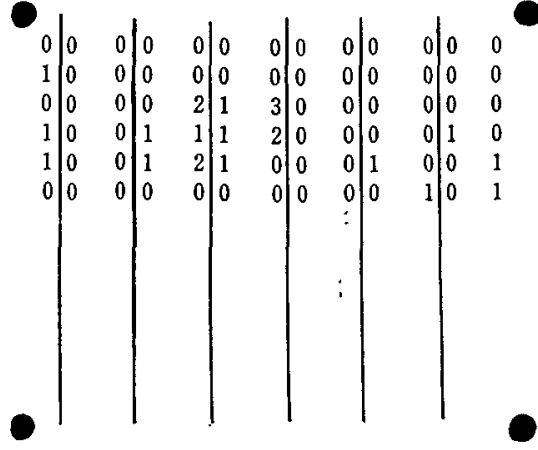

風の弱い日（風向 $\mathrm{SW}$ 風速 $2.0 \mathrm{~m} / \mathrm{s}$ )

サンカクハマキの生存薮 (農薬剂政布後 1 週間 $50 \times 100 \mathrm{~cm}$ 内)

図 6 風の強い場合と弱い場合の防除効果の簀阴

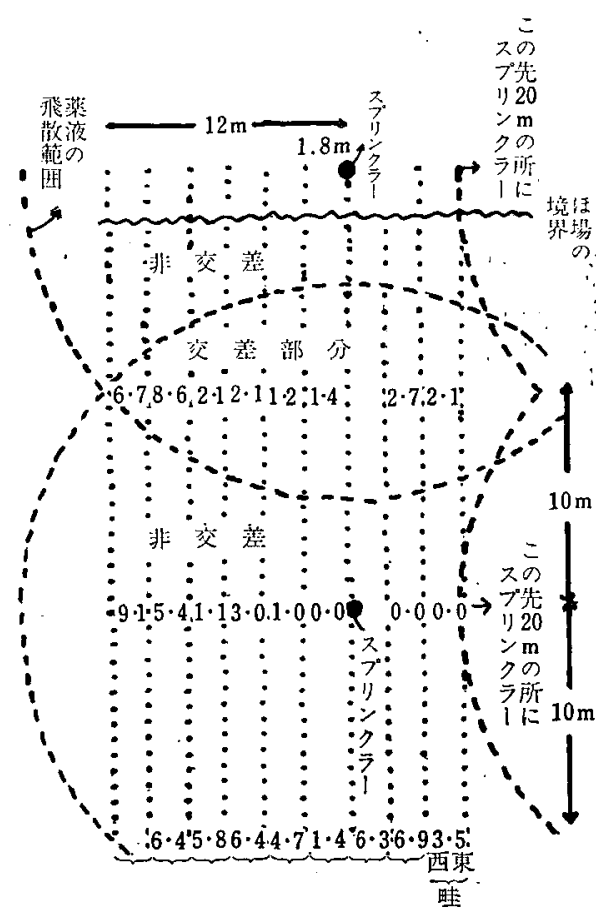

サンカクハマキの農薬散布 1 週問後の生存虫数 (50×100 cm内)の分布

図 7 交差と非交差散布による防除胶果の差異 


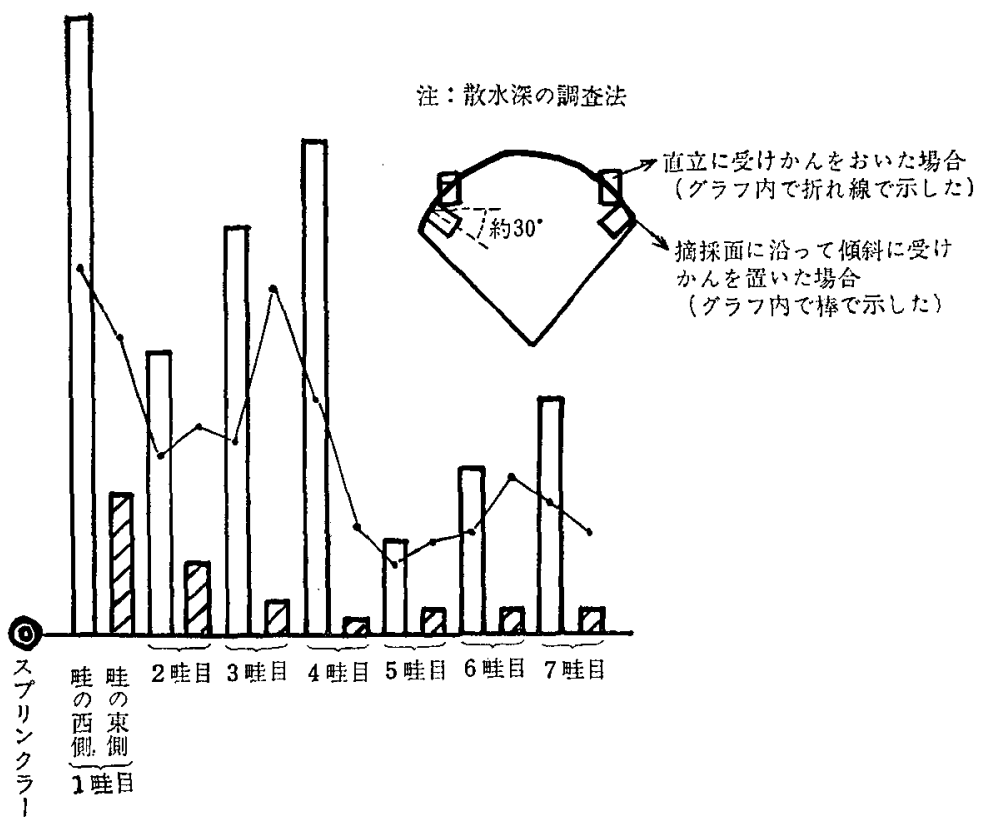

図 8-A 散水の分布（缒い風の場合）

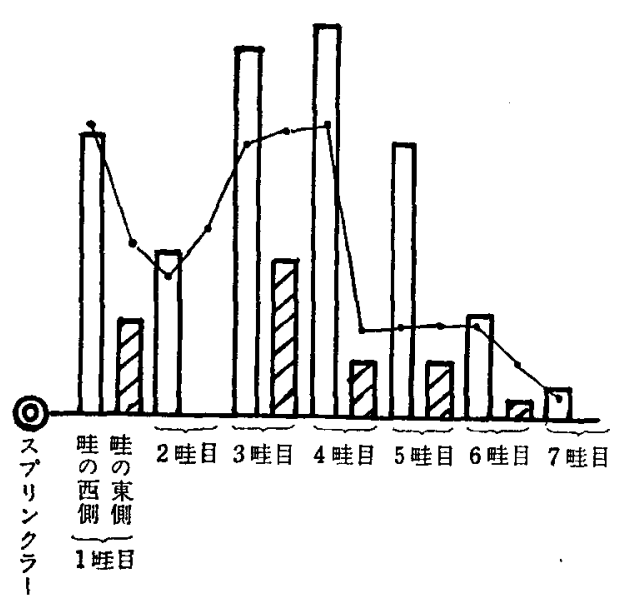

図8一B 散水の分布（向い風の場合）

表 30 カンザワハダニの防除率 (\%)

\begin{tabular}{|c|c|c|c|c|}
\hline 試駼区 & $\begin{array}{l}\text { スプリン } \\
\text { クラ一側 }\end{array}$ & 樹冠頂部 & $\mid \begin{array}{l}\pi フ ゚ リ ン \\
ク ラ-の \\
\text { 反対側 }\end{array}$ & 平 均 \\
\hline $400 l / 10 \mathrm{a}$ & 28 & 33 & 16 & 26 \\
\hline $600 l / 10 \mathrm{a}$ & 54 & 46 & 19 & 40 \\
\hline $1000 / / 10 \mathrm{a}$ & 66 & 65 & 50 & 60 \\
\hline 平 & 49 & 48 & 28 & \\
\hline
\end{tabular}

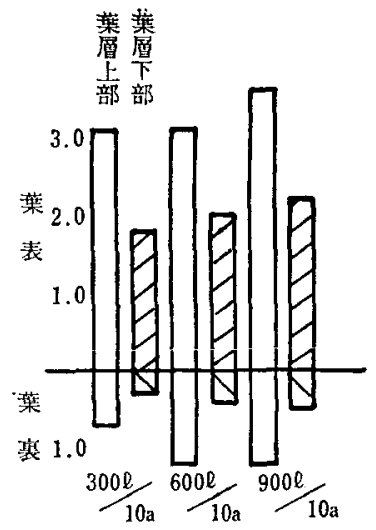

注：付着程度の調查法

銅水和剂を散布し，乾燥後茶葉を取り，水 $(100 \mathrm{cc})$ にフェロシアンカリ $(3 \mathrm{~g})$, 水酭 酸（5cc）を加えた液に万紙を浸し，そのる 紙の上に葉を並べ，さらにその上にろ紙を置 き，ローラにて押え，3日間放置後調查した。 代著昷は次のような方法で判定した。 全然付着しないもの 葉の $\frac{1}{10}$ 程度付着しているすの 1 " $\frac{3}{10} \quad 2$ " $\frac{5}{10}-3$ " $\frac{7}{10}$ " 4 " $\frac{9}{10} " 5$ 図 9 薬液の付着程度 
位による付着量についてみると，葉の表側ではスプリン クラーに面した側の付着がよく，反対侧は惡い。しかし 葉㺧への付着でははっきりした差はみられなかった。こ の付着傾向とカンザワハダニの防除效果はほぼ一致して Wた。

次にスプリンクラーによる周年防除と摘採との関係を 1973，７4 年の防除時期，摘採期を例として表15に示し た。これらのほ場は早, 溜生品程が混在しているため, 主として夏茶期の防除で困難な時期があった。特にチヤ ノホソガの発生は，千ャの生育との関係が樑いので防除 しにくい場合があった。
また，1973年はパダンが摘採 1 週間前まで散布可能で あったので，防除が容易にできたが，1974年は28日に延 びたため適当な楽剂がなく，防除が容易でなかった。し かしこの年は害虫の発生が少なかったため被害は少なか 二た。

さらに現地において，M2型スプリンクラーを18 mx $18 \mathrm{~m}$ の關陾で配管した場合の残液量調查を行った。その

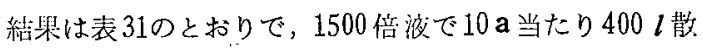
布時の利用率は64\%で，36\%は残液として残り，500 $l$ 散布で $31 \% ， 800 l$ 散布で22\%が残液として残った。

表 31 残 液 量 調 查

\begin{tabular}{|c|c|c|c|c|c|c|c|c|c|c|}
\hline 稀橎倍率 & $\begin{array}{l}87.3 \mathrm{a} \\
\text { 当たり } \\
\text { 散布量 }\end{array}$ & 原液量 & 桸秋资 & 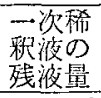 & $\begin{array}{l}\text { 二次厤 } \\
\text { 釉腹量 }\end{array}$ & $\begin{array}{l}\text { 三次稀䣋 } \\
\text { 液残量 }\end{array}$ & 利用率 & 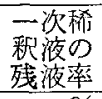 & $\begin{array}{l}\text { 二次稀 } \\
\text { 橎液の } \\
\text { 残液率 }\end{array}$ & $\begin{array}{l}10 \text { a当た } \\
\text { り散帝量 }\end{array}$ \\
\hline \multirow{3}{*}{ 1500倍 } & $3492^{l}$ & $3.6^{l}$ & $389^{l}$ & 35 & 4952 & $1460^{l}$ & $64^{96}$ & 96 & 27 & $400^{l}$ \\
\hline & 4365 & 4.2 & 451 & 35 & 5825 & 1460 & 69 & 8 & 23 & 500 \\
\hline & 7000 & 6.0 & 639 & 35 & 8460 & 1460 & 78 & 6 & 16 & 800 \\
\hline
\end{tabular}

注：1. 一次稀釈液の残液は一次稀釈槽内
2. 二 " 配管内
3. 利用率 $=$ 散布量 $\div($ 原液 $\times 1500) \times 100$
4. 一次稀秎液残液率 $=($ 一次稀釈液残液量 $\times 14) \div($ 原液 $\times 1500)$
5. 二次稀积液残液量 $=$ 二次稀积残液量 $\div($ 原液 $\times 1500)$

\section{4 考察}

\section{1 かん水の効果}

わか国に沶いて，チャに対するかん水の効果について の試験は，1955年から原田らにより行われ，収舅や品質 に対して効果はないであろらと報告されている。その後 10年間はかん水の效果については検討されなかったが， 1965年頃より樹園地の水の必要性が四ばれるよ5にな

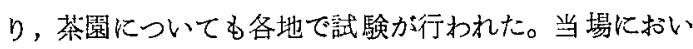
ても，1967年より本場および富士分場において試験を行 い，2 力年の結果が大石らや本杉らにより報告されてい

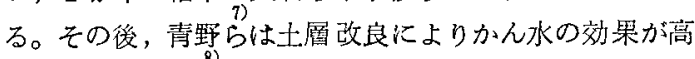
まるとし，淵之上も寒椧地でのかん水の效果の高いこと を報告している。しかし，かん水の効果は気象や土倳々 の関係が深く，永年性作物であるチャにあっては短期間 の試験では十分でないと考え，大石らが開始した試験を 引き続き行って，土鲂条件や気象条件との関係について 検討した。

まず気象条件との関係をみると，降水量あるいは降雨 の分布と年間収量との関係はかなり明確で，1969年は干 ばつ年であったため非常に高く，次いで 1970年の効果も 高かった。反対に 1972年は降水量も多く，降雨の分布も よかったので，かん水効果は宒とんどみられなかった。

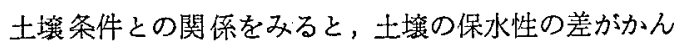

水の頻度抢よび効果の上にはっきりみられた。三つのほ 場の試験が揃っている 1969〜'71年の3カ年のチャの生 育期間（ $3 \sim 11$ 月）のかん水回数は，加らべに園（保水 性が覀い)では年平均 10 回，ふじみどり園が6回，くら さわ轅（保水性が良い）は2.3回となっている。効果の 点です保水性の悪いからべに園のほうがよい結果を得て いる。一方，保水性のよいららさわ園ではほとんど効果 はない。このよ 5 にかん水の効果は, 土壤の保水性むる いは青野らの報告にもみられるように，排水の良否によ っても変わるものであり, 增収効果としては 5 1096と 思われる。

かん水の効果を茶期别にみると, 収量, 品質とすに二 〜三番茶に現れ勿いようである。別の試験（未発表）か らもこのことはらかがわれる。干ばつの期間や程度では 夏季よりも冬季のほ5が綮しいが，冬季は竟発散量が少 なく，地下からの補給水でかなりの部分を補らことがで きるが，夏は蒸発散冒が多く，しかも新芽の生長期でも あるため，水分の不足が収量や品質に影響し易いものと 思われる。しかし幼木園のふじみどりの場合は，一番茶 の収量增加がみられる。ふじみどり園は妸木園であり， 冬季かん水歹行っているので，それらのいずれが原因し ているのかこの試験では判然としない。

次に最適かん水点を調べるため, ポットを用いて試験 を行った結果, 地上部, 根重の増加からみて, pF 2.3 附 


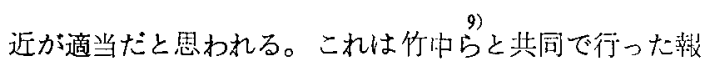
告での推測や，淵之上らの報告とる一致する。

\section{2 液肥 の施用}

スプリンクラーによる液肥の施用については，侍挥ら により非常に効果の高いことが報告されており，尿䕀な どの葉面散布の效果については，青野らにより郝告され ている。しかし液肥の効果や散布方法などについては， 未解決の点すあると考文試験を行った。

まず，液肥を茶園に散布した場合の収量および品賀へ の影㗽についてみると，秋，春肥は有機配合，夏肥に算 肥を用いる慣行区に対し，夏肥のみ液肥を用いた区は収 量では差はなかったが，年間液肥のみを施用した区は年 数が経過するとともに収量が慣行区より少なくなった。 本杉らは年䦧液肥施用により25\%のの増収がみられたと報 告しているが，その後，同じ試験地での結果でも5〜6 鼾の增収にとどまっていることや，本杉らの侙験ではか ん水の效果が含まれていることを併せ教えると，液肥施 用のみでの增収効果は期待できない。干ばつ時にか儿水 を兼ねて施用したときに肥効が高まるすのと思われる。 また年間液肥区の収量が慣行区に比較して少ない原因と して，液肥散布では全面施肥となり，しかも株元にかな りの量が流れるなど，吸収根の多い所への施肥量の少な いことも考えられる。夏肥のみに液肥を偆用するときで も，施肥量を䫧行の場合と同量にした活らがよいと思わ れる。

次に品質については，液肥施用により品夏がよくなる 傾向がみられる。その効果は散有恃期により異なり，開 葉前より開葉期の活うが品質がかなりよいことから考 完，葉面散布の効果もあるものと思われる。

液肥を散花する場合の濃度について検討した結果, 新

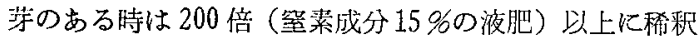
すれば，ほとんど被害は発生しないが，100倍以下では 浱度障害を起こして新芽が枯死または裀变する。古葉で は100 倍程度です被害は発生せず，50倍ぐらいになると 葉の先端や䇚の部分が褐変する。気温による差があるか ぞ5かを一番茶と三番茶の時期について比較したが, 差 は認められなかった。しかし散布後の日射の影響につい ては検討を要する。

次に水の少ない所や土壌状態から，散水量を少なくし たい場合の散布方法として，高湌度で散布し，泩じょ5 する。このときの液肥散布後洗じょ 5 までの経過時間お よび水量について検討した。液肥散布後の洗じょうはで きるだけ早い恬うがよく，少なくとも葉面が乾かないう ちに洗じょうする必要がある。洗じょ5する場合の水量 としては，100 倍液では $1 〜 2 \mathrm{~mm}, 50$ 倍液では $3 \mathrm{~mm}$, 25 倍液では 4 〜 $5 \mathrm{~mm}$ 程度必要となる。䇪菜成分 $15 \mathrm{~kg} /$ $10 \mathrm{a}$ を施用する場合の必要水量をみると, 表 32 のよ5に なり，25倍の高濃度で散布するより，50倍程度で散布し
表 32 穻奖 $15 \mathrm{~kg} / 10 \mathrm{a}$ を施用するに必琶な水量

\begin{tabular}{|c|c|c|c|c|}
\hline 区 & 分 & 散布量 & $\begin{array}{l}\text { 洗じょ5に } \\
\text { 琶する水量 }\end{array}$ & 合計水量 \\
\hline 25 & 僑 & $\begin{array}{l}\mathrm{mm} \\
2.5\end{array}$ & $\frac{\mathrm{mm}}{5}$ & $\mathrm{~mm}_{7.5}^{\mathrm{mm}}$ \\
\hline 50 & 牮 & 5 & 3 & 8 \\
\hline 100 & 售 & 10 & 2 & 12 \\
\hline 200 & 晔 & 20 & 0 & 20 \\
\hline
\end{tabular}

注：液肥は15\%ののものを使用

洗じょうした活うが，水量ではあまり差はなく安全であ る。

茶園の施肥では，夏肥は窒素を主とするし，液肥より 少佂な単肥を溶かして政有することも有效であるが，硫 安は溶け難く，被管の発坐も多いのでスプリンクラーに 上る施用には適さない。その点，尿菜愹け罗く，被害 の発生も少ないので使用し易い。浱度としては，窒祘成 分で液肥の濃度と合わせればよいものと想われる。

1 回の散布量としては， $5 \mathrm{~mm}$ 以下では茶臌や敨草に 付着して根群域侄到するものが少ないので， $5 \mathrm{~mm}$ 以 上とした活5がよい。最高は一般の施肥と同㥞，窒素成 分で $15 \mathrm{~kg} / 10 \mathrm{a}$ 以下にとどめ, 土壤水分を考虑して头め るべきすのと思われる。

以上のことから，スプリンクラーによる施肥は，一番 茶前の芽出し肥加夏期に利用し，秋肥と春肥は慣行法 で行うのがよいと思われる。稀粎濃度としては，新芽の ある時は200 倍（窒菜成分15\%の液肥の場合），新菲のな い時は 100 倍程度とするのが適当であり，1回の散布量 は 5〜10 $\mathrm{mm}$ 程度とするのがよいと思われる。

\section{3 病害虫防除}

病㕩虫防除については，本杉らや小泊ら，大場などに より防除効果の高いことが派告されている。著者らも $\mathrm{M}$ 2 型スプリンクラーを中心検討した。噴出角度の低い M 2 型スプリンクラーとM1型スプリンクラーについて 比較した結果は，それほど大きな差はないことが認めら

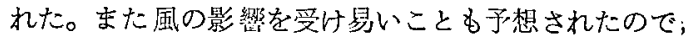
風速 $3.0 \mathrm{~m} / \mathrm{sec}$ ぐらいまでの均等性について調查した が，M2型スプリンクラーでも風によりそれほど乱され なかったことから，M 2 型スプリンクラーでも害用上は 問題がないと思われる。しかし噴出角度の高いるのは， 風の影響を受け易く防除に优用できなかった。

次に交差散布と無交差散布の效棵について調查した結 果，無交差散布では，スプリンクラーから3〜4 mまで は薬液の付着がよいが，さらに離れるとスプリンクラー の反対侧のうね面は付着が悪くなる。この点は防除効果 からも認められる。こ5いったことから配管に当たって は，できるだけ交差させることが望むしいし，交差させ ない場合でも, 散布半径（約 $15 \mathrm{~m}$ ) 上り $3 \sim 4 \mathrm{~m}$ 長いく らいに配管すべきであると思われる。薬液の付着は風速 
や風向によっても異なる。追い風のような場合は，スプ リンクラーと反対側のう槒は付着が悪いが，向い風の 場合は押し戻されるよ5に水滴が落ちるので，スプリン クラーの反対側でも付着がよくなる。

スプリンクラーによる防除の難点の一つは, 風の影響 を受け易いことである。風のやや強い時 $(6.0 \mathrm{~m} / \mathrm{sec})$

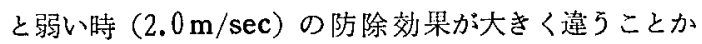
らも，できるだけ風の少ない時に行う必要がある。

またカンザワハダ二の防除も容易でないが，防除効果 を高めるため散布量を多くして調查した。葉裹に答生す るカンザワハダ二の防除では，散布量を 800〜1,000 l/ 10 a 增加する必要がある。それと同時に，大場らが指 摘しているように，故出牦度の低いスプリンクラーを用 いライザーの高さを株面から $20 〜 30 \mathrm{~cm}$ ぐらいにした 汪らが效果が高い。

次に周年スプリンクラーによる防除を行う場合，早， 晚生品種が混在していると，一，二番茶や二，三番茶の 茶期の間が問題となる。チャノホソガの防除は摘採前 10 〜15日に行わないと被害の発生が多くなるが，早，晚生 品種が混在していると適期防除が图難となる。またチャ 八マキなどについても，発生のピークがはっきりしない ような時, 低漘度では十分の効果があげられないような こともある。害出の虫令と薬液の濃度との関係について 検討する必要がある。

次に残液量について現地の施設について調査した。残 液量は濃度や散有量との関係はあるが，1500倍で $400 l$ $10 \mathrm{a}$ を散布する場合，約 $36 \%$ 残ることになる。その内訳 をみると，一次稀譒液槽に $9 \%$ ，配管内に $27 \%$ となり， 薬液代を增加させている。一次稀釈液槽の残液は，蒋造 を改善すれば伯には落すことができる。二次稀粎液の 残液は，配管の工夫だけではそれ汪ど減少しないので， コンプレッサーによる押し出し，あるいは他の方法によ り押し出して利用することが必要である。

なお，残された問題としては，可搬型㨳採機等による 摘採に障害となるライザーの除去, 薬液の飛散防止, 傾 斜地での配管方法などがある。

\section{5 摘 要}

茶園に打けるスプリンクラーの多目的利用の5ち，か 儿水の効果，施肥，病害虫防除について検討した。

1. かん水の効果 気象条件とかん水の効果との関係は かなり明確で，降水量が少ないか降雨の分布の悪い年 はかん水の効果が高い。土㙵の保水性とかん水の效果 との関係もかなりはっきりして㧍り，保水性の悪い忹 場はかん水回数が多く，かん水の効果も高い。茶期別 のかん水の影響では，二〜三番茶での効果が高い。

品筫に刘する影響をみると，干ばつ時にかん水する ことにより品質が向上する傾向がみられた。
土壤水分張力をもとに最適かん水点を調べた結果， pF 2.3 程度でか九水したものが生育は最もよかった。

2. 施肥 年間波肥の及を施用した場合, 慣行施肥区よ り収量が減少した。液肥を利用する方法としては， 秋，春肥は慣行法により，夏肥のみ液肥を用いるのが 適当と考克られる。

液肥を施用することにより品䨘が向上した。特に開 葉期の散布の効果が简かった。

散布する液肥の濃度としては，新芽のある時は 200 倍（音素濃度 $15 \%$ の液肥の場合），新芽のない場合は 100 倍程度とすればよい。

単肥を溶かして使用する場合は尿素が適しており， 硫安は被害が発生し易く不適当である。

3. 病害虫防除 $\mathbf{M} 2$ 型スプリンクラーを中心に検討し た。

M 2 型スプリンクラーと M 1 型スプリンクラーを比 較すると，防除効果ではM 2 型がやや劣るものの，い ずれのスプリンクラーを使用しても実用上は問題がな い。

交差散布と無交差散布での防除效果を比較すると， 交差散布の效果が高い。配管に当たっては最大限散布 半径（約 $15 \mathrm{~m}$ ) より $3 \sim 4 \mathrm{~m}$ 長い程度にするのが適当 である。

スプリンクラーによる莯剂散布は，風の影響を受け 易いので，できるだけ風の弱い時を選んで散布すると 同時に，唺出角度の低いスプリンクラーを使用したほ うがよい。

ダ二類の防除に当たっては，散布量を $10 \mathrm{a}$ 当たり $800 \sim 1000 l$ 程度とする (一般の防除では 400 500l./ $10 \mathrm{a}$ が適当とされている)。

スプリンクラーにより周年防除を行らには, 早, 晚 生品種が混在していると防除が困難な時期がある。品 種統一が必要である。

現地の施設について, 残液量を調查した結果, 濃度 により差はあるが， 1500 倍で $400 l / 10$ をを散布すると 原液换算で約 $36 \%$ が残る。一次稀彩液槽の構造を工夫 するとともに，配管内の残液を押し出す施設を侏設す ることが必要である。

本試験を行うに当たり，いろいろと御助言をいただい た当場璪境研究の小泊重洋主任研究員, 大場正明技師に 厚く感謝の意を表する。なお，本報をとりまとめるに当 たって，䅰切なるご指導を賜った農林省茶業試験場茶樹 第 3 研究室 青野英也室長に対し厚く劺礼申し上げる次第 である。 


\section{6 引用文 献}

1）本杉昭二, 望月勝已，勝又美亘：日農気東海支部 誌, No. 17, 1 5 (1968).

2）小泊重洋，大場正明，笹野昭男：静岡茶試研報， No. 6, 33 48 (1975).

3) 大場正明：植物防投，27，No. 8，39 42 (1973).

4）原田重雄，三ツ井稔：東近農試研報（茶），No.5, 57 76 (1957).

5）大石貞男，鈴木幸隆，木村政善：静岡茶試研報， No. 3, 21 72 (1970).

6）本杉昭二，望月勝己，勝又美亘，持塚兼吉，黑田唀

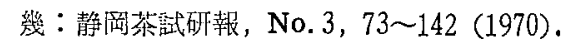

7）青野英也，築濑好充，田中静夫：茶技研，No. 49, 13 49 (1975).

8）淵之上弘子：茶技協講要，Feb. 1977，20.

9）竹中 㢣，大石貞男，跉木幸隆，木村政美，此本晴 夫, 持潒蒹吉, 大場正明: 静岡荼訌研辩, No. 4 , $21 \sim 50$ (1971).

10）持塚兼吉，大場正明，加藤栄一，本杉炤二，望月勝 己: 静岡茶試研報, No.4 , 51 58 (1971).

11）青野英也，高橋恒:二: 茶研報，No. 1，25３0 (1953).

(Aug. 10, 1977) 